\title{
WestVirginiaUniversity
}

THE RESEARCH REPOSITORY @ WVU

Graduate Theses, Dissertations, and Problem Reports

2010

\section{Phosphorus nutrition in broilers}

Staci Ann Loop

West Virginia University

Follow this and additional works at: https://researchrepository.wvu.edu/etd

\section{Recommended Citation}

Loop, Staci Ann, "Phosphorus nutrition in broilers" (2010). Graduate Theses, Dissertations, and Problem Reports. 3025.

https://researchrepository.wvu.edu/etd/3025

This Thesis is protected by copyright and/or related rights. It has been brought to you by the The Research Repository @ WVU with permission from the rights-holder(s). You are free to use this Thesis in any way that is permitted by the copyright and related rights legislation that applies to your use. For other uses you must obtain permission from the rights-holder(s) directly, unless additional rights are indicated by a Creative Commons license in the record and/ or on the work itself. This Thesis has been accepted for inclusion in WVU Graduate Theses, Dissertations, and Problem Reports collection by an authorized administrator of The Research Repository @ WVU. For more information, please contact researchrepository@mail.wvu.edu. 
Phosphorus Nutrition in Broilers

Staci Ann Loop

Thesis submitted to the

Davis College of Agriculture, Natural Resources and Design at West Virginia University

in partial fulfillment of the requirements for the degree of

\author{
Master of Science \\ in \\ Animal and Nutritional Sciences \\ Joseph Moritz, Ph.D., Chair \\ Ken Blemings, Ph.D. \\ Janet Tou, Ph.D.
}

Division of Animal and Nutritional Sciences

Morgantown, West Virginia

2010

Keywords: phytase, phosphorus, feed manufacture, pellet quality, broiler performance, poultry litter ash 


\section{ABSTRACT \\ Phosphorus Nutrition in Broilers}

Staci A. Loop

Due to depleting resources, high feed ingredient costs, and eutrophication, phosphorus nutrition in broilers has been a topic of concern for many years. The amount of damage being done to the environment by phosphorus runoff in some states has lead to regulations that require broiler litter to have decreased phosphorous with the use of a phytase enzyme. There are many phytase products on the market, however, these enzymes are not all equally effective. Companies may rely only on feed manufacture retention data instead of conducting live bird performance research to test the actual efficacy of the enzyme. The first study addressed this problem by measuring in vitro retention of 9 enzymes with in vivo live bird performance variables. Results showed discrepancies between these two parameters, suggesting that enzyme efficacy should be assessed with both in vitro and in vivo studies. A second study was conducted to test the effect of poultry litter ash on feed manufacture variables as well as live bird performance variables. This study was based on the concept that poultry litter ash could replace rock phosphorus sources in the diet, therefore reducing diet cost while maintaining similar live bird performance and feed manufacture variables. Results suggested that the poultry litter ash may possess some pellet binding qualities and can increase pellet quality. Results also suggest that poultry litter ash provides utilizable phosphorus and calcium for bone mineralization, but may have some anti-nutritional factors that caused decreased live bird performance. 


\section{Acknowledgements}

It is with sincere gratitude that I thank my family, friends, and colleagues for their support throughout this process. I would like to thank Dr. Moritz for the opportunity to conduct this research as well as the guidance he provided throughout. The help of my lab group, Laurel Shires, Curran Gehring, Kala Beaman, Kelley Lilly, and Brittany West was invaluable. I would also like to thank Jessica Springman as well as the undergraduates who helped with the long days of feed manufacture, weighing, and tibia extractions. I would like to thank all of the staff and faculty of the Division of Animal and Nutritional sciences, including Sarah Beamer, Tammy Webster, and Rick Wood. Lastly, I would like to thank my family for their continued love and support through all of my educational endeavors. 


\section{TABLE OF CONTENTS PAGE}

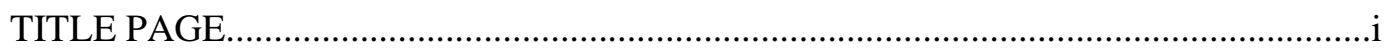

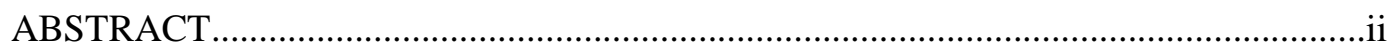

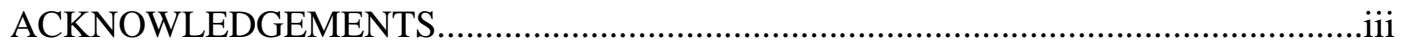

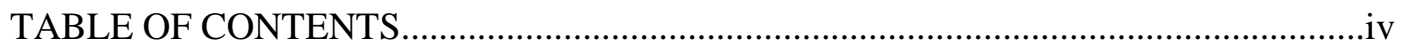

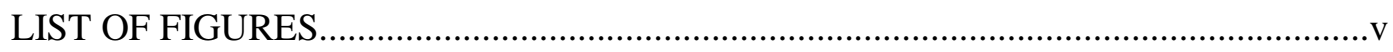

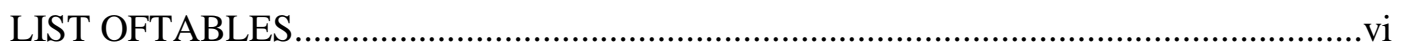

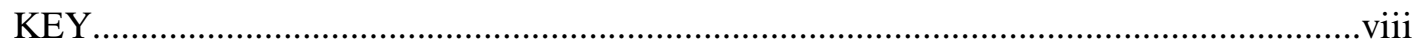

\section{CHAPTER ONE}

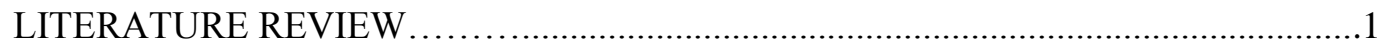

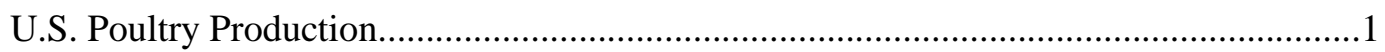

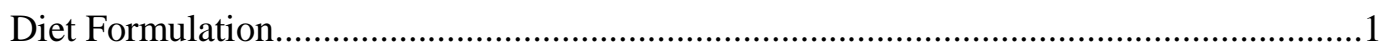

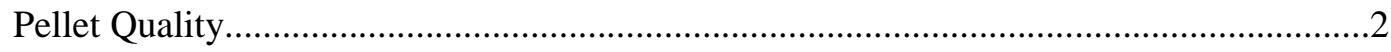

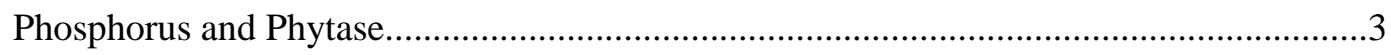

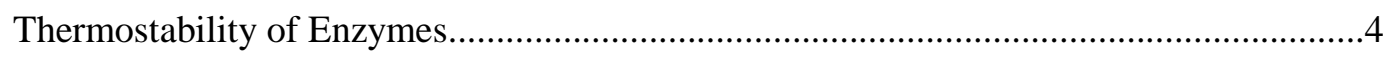

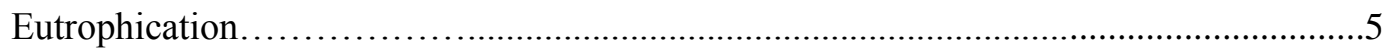

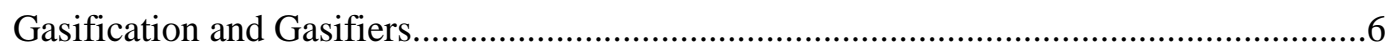

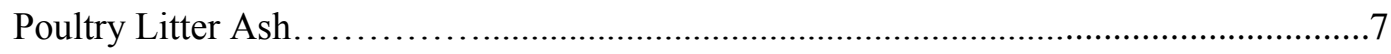

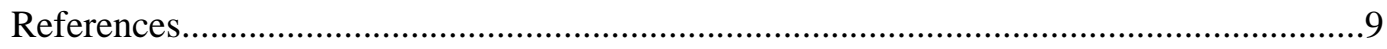

\section{CHAPTER TWO}

\section{IN VITRO TESTING OF PHYTASE RETENTION POST-PELLETING MAY NOT}

ADEQUATELY PREDICT EFFICACY ...............................................12

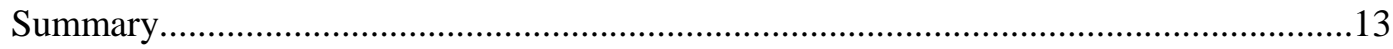

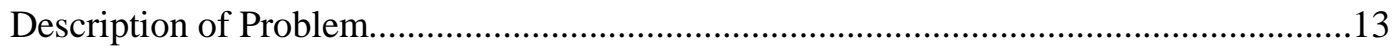

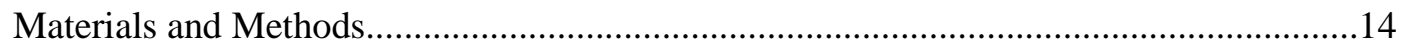




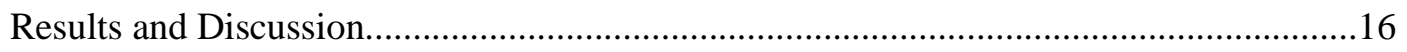

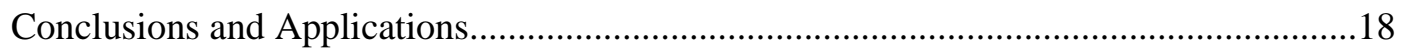

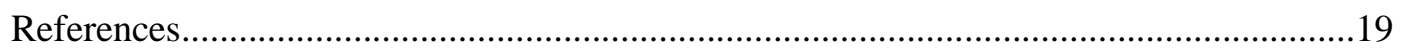

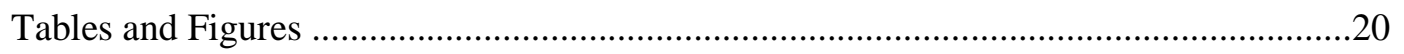

\section{CHAPTER THREE}

EVALUATION OF THE EFFECTS OF POULTRY LITTER ASH ON FEED

MANUFACTURE AND PERFORMANCE VARIALBES IN BROILERS....................26

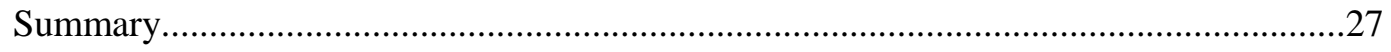

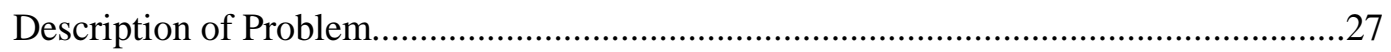

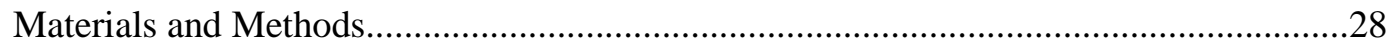

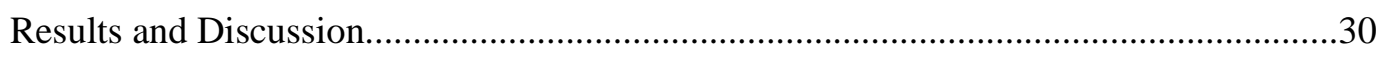

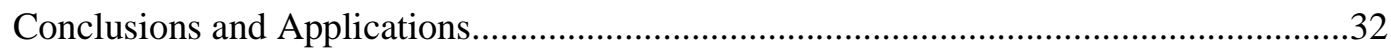

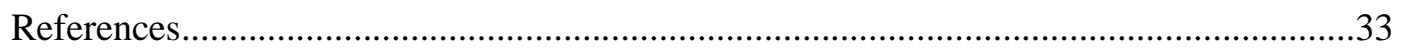

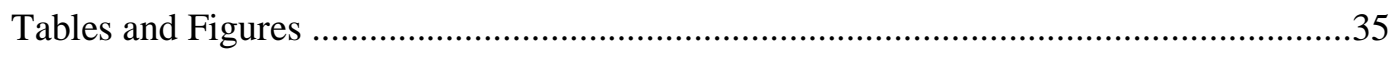

\section{LIST OF FIGURES}

\section{CHAPTER TWO}

Figure 1. Enzyme retention of pellets conditioned at $71^{\circ} \mathrm{C}, 77^{\circ} \mathrm{C}$, and $82^{\circ} \mathrm{C}$

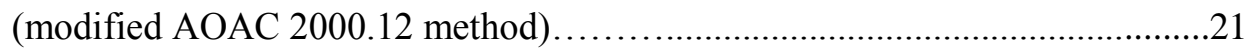

Figure 2. Enzyme Retention of Pellets Conditioned at $77^{\circ} \mathrm{C}$

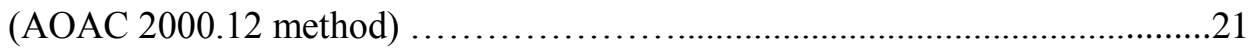

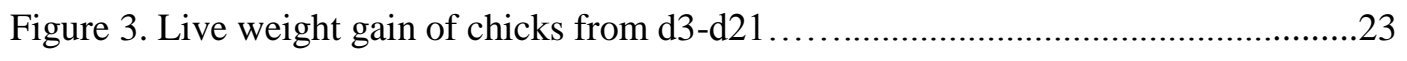

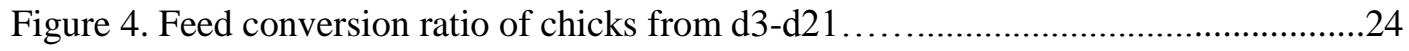

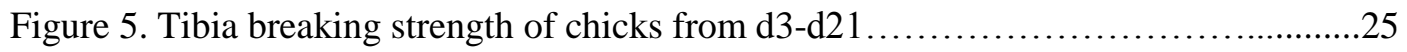

Figure 6. The effect of E. coli derived phytase on tibia ash of chicks from d3-d21......25 


\section{CHAPTER THREE}

Figure 1. The effect of PLA on pellet mill relative electrical energy use..................37

Figure 2. The effect of PLA on production rate. ................................. 37

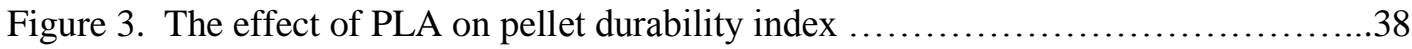

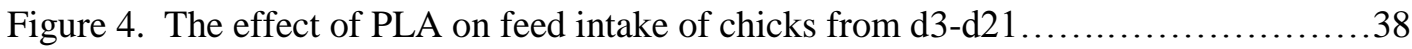

Figure 5. The effect of PLA on live weight gain of chicks from d3-d21 .................39

Figure 6. The effect of PLA on feed conversion ratio of chicks from $\mathrm{d} 3-\mathrm{d} 21 \ldots \ldots \ldots \ldots \ldots . . . . .39$

Figure 7. The effect of PLA on tibia ash of chicks from d3-d21 .......................40

\section{LIST OF TABLES}

\section{CHAPTER TWO}

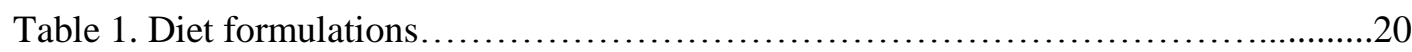

Table 2. Percent moisture of pellet samples taken directly off the cooler belt.............21

Table 3. Pellet durability index................................................ 22

\section{CHAPTER THREE}

Table 1. Proximate analysis values of poultry litter ash..............................

Table 2. Mineral content of poultry litter ash...................................... 35

Table 3. Diet formulation.....................................................

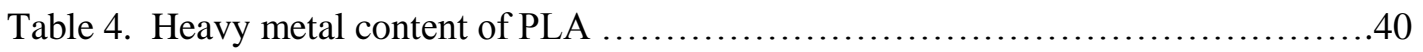


KEY

CHAPTER ONE

L:D-length (thickness) to diameter (hole diameter) ratio of the pellet die

IP6- Myo-inositol 1,2,3,4,5,6- hexakis dihydrogen phosphate

CAFO- Confined animal feeding operation

SWCP-Soil and water conservation plan

NMP- Nutrient management plan

BMP- Best management practices

PLA- Poultry Litter ash

CHAPTER TWO

PC- Positive control

NC- Negative control

NPP- Non-phytate phosphorus

FTU/kg - Phytase units per kg

PDI- Pellet durability index

MPDI- Modified pellet durability index

LWG- Live weight gain

FI-Feed intake

FCR- Feed conversion ratio

CHAPTER THREE

PLA- Poultry litter ash

NC-Negative control

PC-Positive control

NPP- Non-phytate phosphorus

FI- Feed intake

LWG- Live weight gain

FCR- Feed conversion ratio

PDI- Pellet durability index

MPDI- modified pellet durability index 


\section{Literature Review}

\section{U.S. Poultry Production}

The United States is the world's largest poultry producer and the second-largest egg producer and exporter of poultry meat. U.S. poultry meat production consists of over 43 billion pounds annually with four fifths being broiler meat. Total farm value of the U.S. poultry industry exceeds $\$ 20$ billion with broiler production accounting for the majority (USDA 2009). Most broiler production in the United States is done by growers under contract by a much larger company or processor. The grower typically supplies the growout house, which includes necessary heating, cooling, watering, and feeding devices. The grower also supplies the labor needed to maintain proper growth of the birds. The company supplies the chicks, feed, veterinary care, and transportation of the birds to the processing plant.

West Virginia is ranked \#15 in poultry production. Broilers are the number 1 agricultural commodity in the state consisting of $31.5 \%$ of the total farm receipts and contributing to $0.7 \%$ of the U.S. value. Total poultry and products in WV total $\$ 32.9$ million (USDA, 2008).

\section{Diet Formulation}

Diet formulation is one of the most important factors that influence bird performance. Most diets are formulated to be as inexpensive as possible while meeting the nutritional requirements of the animal. This gives way to the multitude of ingredients used in poultry diets. However, different ingredients cause differences in pellet quality. Pellet quality has been defined as the ability of a feed pellet to maintain postmanufacturing integrity throughout the mechanical agitations produced by conveying, shipping and handling by birds (Cramer et al., 2003). In addition, the processing history and origin of the ingredient may influence the physicochemical properties and their effect on the pelleting process.

Feed ingredients are comprised of starch, protein, sugar, non-starch polysaccharides, lipids, inorganic matter, and water (Thomas et al., 1998). Most broilers are fed corn and soybean meal based diets. These two ingredients are essential in the starch gelatinization process required to produce pellets of increased pellet quality. This has caused problems in recent years due to the drastic increase in corn 
prices in the United States. Fat prices have also increased. Current industry practice has been to keep the inclusion level of fat low to reduce cost and improve pellet quality (Gehring et al., 2009). However, mixer-added fat may display benefits such as improved nutrient utilization and enzyme efficacy by coating feed particles (Eliasson et al., 1981, Zimonja et al., 2007) and lubrication of the pellet die (Cutlip et al., 2008).

\section{Pellet Quality}

More than $80 \%$ of all non-ruminant feed in the U.S. is pelleted (Behnke, 1996). The cost of pelleting can be justified by the benefits, which include: 1) decreased feed wastage; 2) reduced selective feeding; 3) decreased ingredient segregation; 4) decreased time and energy expended for prehension; 5) destruction of pathogenic organisms; 6) thermal modification of starch and protein; 7) increased digestibility; and 8) improved palatability (Behnke, 1994).

Pellet quality is often overlooked due to least-cost diet formulations and high feed throughput of feedmills. Feeding pellets of high quality (94 pellet durability index, 5\% fines) was shown to decrease broiler feed intake and feed conversion ratio compared to broiler fed lower quality pellets (90 pellet durability index, 9\% fines) (Cutlip et al.,2008). In a similar study, Lilly et al (2009), using the same diet formulations, determined that increasing pellet quality from $60 \%$ to $90 \%$ pellets in the feed pan increased broiler carcass weight by almost 2 -fold.

Reimer (1992) concluded the factors influencing pellet quality in the following order: diet formulation (40\%), conditioning parameters (20\%), particle size (20\%), die specification (15\%), and drying/ cooling (5\%). These factors are important, however Thomas et al. (1997) suggested that pellet quality may be influenced more by equipment than diet formulation. Buchanan et al. (2008) reported die length to diameter (L:D) plays a significant role in pellet quality as well as ambient temperature. Gehring et al. (2009) concluded that all factors were important and that interactions among factors may exist.

Factors that may increase pellet quality may also have a negative effect on nutrient availability as well as enzyme efficacy. Increased pellet quality is seen by increasing both pressure and temperature during conditioning (Cutlip, 2008). However, increasing temperature too much may have a negative 
effect on enzyme retention due to denaturation of the protein. Decreased addition of mixer-added fat may increase pellet quality, however Gehring et al (2009) found that increasing the amount of mixer-added fat reduced the extent of exogenous enzyme and amino acid degradation.

\section{Phosphorus and Phytase}

Approximately $2 / 3$ of the phosphorus in mature cereal grains is present in the phytic acid molecule, causing this phosphorus to be poorly available. Phytic acid (IP6) readily binds mineral cations, and in this form is knows as phytin. Myo-inositol 1,2,3,4,5,6-hexakis dihydrogen phosphate (IP6), an organic phosphate, is a phosphorylated cyclic sugar alcohol. IP6 in plants exists as phytate in its anionic form, however in mature seeds it is found as a chelated molecule as phytin (Lott, 1984).Some discrepancies exist among terms used in describing amounts of phosphorus. Total phosphorus refers to any and all phosphorus in the diet. Available phosphorus is any phosphorus in the diet that is absorbed by the animal. Retained phosphorus is any phosphorus that remains in the body. Any phosphorus that is not bound to the phytin molecule is referred to as non-phytin phosphorus. Phytin is found primarily in seeds, but the location of the phytin varies amoung plants. Ninety percent of phytin in corn is found in the germ portion of the kernel (O'dell, 1976). However, in soybean seeds, phytin has no specific site (Ravindran, 1995). In seeds, phytin acts as: 1) a phosphorus reserve, 2) an energy store, 3) a competitor for adenosine triphosphate during the rapid biosynthesis of phytin near seed maturity when seed metabolism is inhibited and dormancy is induced, 4) an immobilizer of divalent cations needed for the control of cellular processes and that are released during germination upon the action of intrinsic plant phytases, and 5) a regulator of readily available seed inorganic phosphorus level (Cosgrove, 1980). Phytate is also considered antinutritive (Pallauf, 1997) in that it chelates important dietary minerals such as zinc, copper, magnesium, and calcium, as well as protein and starch. Proteins bind directly to IP6 through electrostatic charges at low $\mathrm{pH}$ or through salt bridges formed at high $\mathrm{pH}$ (Graf, 1986). Starch binding occurs as a result of hydrogen bond formation (Thompson, 1986). Binding of starch and proteins to IP6, like phosphorus, renders them unavailable. Phytases (myo-inositol hexaphosphate hydrolases) are phosphatase enzymes able to catalyze the hydrolysis of phosphate ester bonds. There are four possible 
sources of phytase that can be found in the digestive tracts of animals: 1) phytase already present in feed ingredients, 2) exogenous microbial phytases added to the diet, 3) phytases produced by microflora present in the GIT, and 4) intestinal mucosa membrane linked phytase (Angel, 2002). Although phytases are naturally occurring enzymes in plants and animals, poultry produce minimal endogenous phytase (Nelson, 1976). Two classes of phytase enzymes exist; a 3-phytase and a 6-phytase which cause dephosphorylation of the IP6 molecule at either the 3 or 6 position on the inositol ring, respectively. Unlike the 6-phytases, the 3-phytases do not always completely dephosphorolate IP6 (Wodzinski, 1996). Generally, microorganisms produce 3-phytase while plants produce 6-phytase (Reddy, 1982 and Nayini, 1986), however Phillippy et al. reported 3-phytase in soybeans and Greiner et al. reported 6-phytase activity in Escherichia coli. Microbial phytases tend to have $\mathrm{pH}$ optima in the range of 2 to 6, whereas plant phytases tend to have a pH optimum near 5 (Wodzinski, 1996). Adding phytase to feed significantly increases phosphorus availability and utilization (Ravindran et al., 1995) Cultures of E. coli are often used to produce phytase because it can produce the enzymes quickly, produces high yields, and is less prohibitive than other methods (Viveros et al., 2002).

\section{Thermostability of Enzymes}

The structure of an enzyme is critical to its function. The primary and secondary structure of an enzyme can be altered by exposture to heat, $\mathrm{pH}$ extremes, and certain organic solvents. All of these factors can decrease enzyme activity or completely eradicate it (Spring, et al., 1996). Feeds produced for the broiler industry are often pelleted using saturated steam at high temperatures that can alter the enzyme efficacy. A study done by Kirkpinar et a. in 2006 showed that steam pelleting at a temperature higher than $60^{\circ} \mathrm{C}$ reduced the phytase activity of some preparations. Pointillart and Hughes reported decreased phytase activity when pelleting at temperatures upwards of $75^{\circ} \mathrm{C}$. The maximum conditioning temperature that a specific phytase can survive depends on the form it is in as well as the type. Methods for increasing thermostability of enzymes are; carbohydrate/lipid coatings (Bedford, 2001), genetic modification of the enzyme (Gentile, 2003), as well as using naturally heat stable sources (Pasamontes, 1997). These 
methods are used alone as well as in conjunction with each other. Enzymes must survive the pelleting process however, they must also be able to be utilized by the animal.

\section{Eutrophication}

Eutrophication can be defined as an increase of the rate of supply of organic matter (Nixon, 1995). Eutrophication results in oxygen depletion (hypoxia), an increased turbidity, loss of submersed vegetation, and alteration of food webs (Boesch et al, 2001). For most of the $20^{\text {th }}$ century, public concern, along with scientific research and policies were directed toward such problems as overharvesting of fisheries (specifically oysters), infectious wastes, industrial and municipal pollution, toxic pesticides, wetland loss, channel dredging and soil disposal, and power plant effects (Davidson et al., 1997). These issues were considered localized problems, with the exclusion of overharvesting. However, in the last quarter of the century it has become apparent that eutrophication has critically affected entire bodies of water, and more locally, the Chesapeake Bay.

Depletion of dissolved oxygen by the decomposition of organic matter, either added to the ecosystem or produced within the ecosystem as a result of the stimulating effects of nutrient inputs is the most severe consequence of eutrophication. Anoxia (lack of oxygen) or hypoxia (dissolved oxygen concentrations lower than required by indigenous organisms) is a particular concern. Organic matter produced in lighted surface waters sinks to the bottom waters where it decomposes, consuming oxygen where it is not replenished by photosynthesis or mixing with oxygen-rich surface waters (Broesch 2001). Over enrichment of waters causes massive blooms of cyanobacteria and macroalgea which results in depleted oxygen (Jaworski, 1990). Consequently, this causes fish kills and disrupts entire food chains.

Agriculture is the largest source of nitrogen and phosphorus entering the Chesapeake Bay. In order to reduce the amount of nutrients entering the bay, regulations have been implemented in states most heavily effecting eutrophication. Efforts have been focused on education, technical assistance, and cost-share programs for individuals running CAFOs (Confined Animal Feeding Operations). Regulations such as Soil and Water Conservation Plans (SWCPs), Nutrient Management Plans (NMPs), and state agricultural cost-share programs that provide money to landowners for implementing practices prescribed in the plans. 
These Best Management Practices (BMPs) are techniques that help prevent soil erosion, reduce unneeded nutrient application, and control nutrient movement (Boesh, 2001). SWCPs focus on stream and bank protection measures (eg. fencing, livestock crossings, animal waste storage structures, etc.). NMPs are designed to acquire a more accurate estimate of the levels of nitrogen and phosphorus that are being produced by individual CAFOs.

Currently $97 \%$ of poultry sales in the U.S. are controlled by operations that each produce more than 100,000 broilers a year (Gardner, 1998). On average, only $30 \%$ of the fertilizer and feed phosphorus input to farming systems is output in crop and animal produce. Thus there is the tendency for phosphorus to accumulate in CAFOs (Sharpley, 1999), and consequently runoff into waterways.

In the summer of 1997, toxin-producing dinoflagellate Pfiesteria piscida were targeted as the cause for fish kills in North Carolina. This outbreak was made more likely or severe due to enrichment of water with organic matter or nutrients (Burkholder and Glasgow, 1997). Further concern over the toxic Pfiesteria outbreaks was exacerbated by documentation of short-term memory impairment and other effects in humans exposed to Pfiesteria (Gratten et al., 1998). The Chesapeake watershed model estimates that $60 \%$ of the nitrogen inputs from the Maryland eastern shore to the Bay are from agriculture, and approximately half that amount is from animal manure. Poultry manure is relatively rich in phosphorus in relation to the nitrogen to phosphorus requirement of crops, resulting in repeated manure application, and a subsequent increase in dissolved phosphorus in surface runoff (Sharpley, 1995; Staver and Brinsfield, 1995b; Carpenter et al., 1998).

\section{Gasification and Gasifiers}

Gasification is defined as the thermo-chemical conversion of a solid or liquid carbon-based material into a combustible gaseous product by the supply of a gasification agent (Belgiorno et al., 2003). The idea of gasification to produce an energy source has been around for years but interest in the process has risen due to the realization of problems facing global energy use. Gasifiers can be classified into two types; fixed-bed and fluid-bed. Of these two categories fixed-bed gasifiers can be classified further into updraft, Imbert downdraft, throatless downdraft, crossdraft and two stage gasifiers. Each of these 
gasification systems are specific for the type of material being processed, moisture content of the material, as well as temperature range.

The fixed bed gasifier has a bed of solid fuel particles through which the gasifying media and gas move either up or down. It is the simplest type of gasifier usually consisting of a cylindrical space for fuel and gasifying media with a fuel feeding unit, an ash removal unit, and a gas exit. In the fixed bed gasifier, the fuel bed moves slowly down the reactor as the gasification occurs. The fixed bed gasifiers are of simple construction and generally operate with high carbon conversion, long solid residence time, low gas velocity and low ash carry over (Carlos, 2005; Reed and Das, 1988). Fixed bed gasifiers can be classified by which way the gasifying agent enters the system i.e. updraft, downdraft, crossdraft, two stage. The gasifying media can be air, oxygen, steam, or a mixture of gasses. The result of gasification is heat, gas (syngas), tar, and char or ash. After purification, the syngas can be used as a fuel source. Two stage gasifiers separate the pyrolysis zone (first stage) from the reduction zone (second stage). The gasifier has two levels of air intakes, primary air supply at the top section and secondary air at the middle section of the gasifier. The high temperature achieved in the second stage due to the addition of a secondary air helps in reducing the tar level to a considerably lower value (Chopra and Jain, 2007).

\section{Poultry Litter Ash}

Poultry litter ash (PLA) is produced by the gasification process of poultry litter. This process is beneficial to both the producer and the environment. Poultry litter stored in CAFOs or spread on fields poses the potential risk of runoff and subsequent eutrophication of waterways. The gasification of this poultry litter substantially reduces the volume of waste and may be more easily transported and stored.

PLA is high in phosphorus and potassium, making it a viable source of fertilizer for crops (Codling et al, 2002). The high amount of phosphorus also could prove PLA to be useful in poultry nutrition as a replacement for rock phosphorus. In early January 2008, suppliers of feed phosphates announced to their customers that supply of phosphates would not be enough to meet orders from the animal feed industry due to exceptionally high demand for phosphorus containing fertilizers (feed phosphates and fertilizers are both produced from a common raw material). These global shortages result from a combination of 
increased global demand, poor harvests, and the emergence of the bio-fuels industries which divert cereals and oil from plant protein sources into bio-ethanol and bio-diesel production (Aviagen, 2008).

Although it would seem that PLA would be a logical replacement of rock phosphorus, only one published study exists. Akpe et al. conducted a study in 1984 to determine the composition and phosphorus bioavailability in poultry litter biomass ash residue samples included in diets for young turkeys. The results of the study found PLA to be a potential phosphorus source in broiler diets. 


\section{REFERENCES}

Akpe, M.P., P.E. Waibel, and R.V. Morey. 1984. Bioavailability of phosphorus in poultry litter biomass ash residue for turkeys. Poultry Sci. 63:2100-2102.

Aviagen Global Nutrition Team. 2008. Global Feed Phosphate Shortage. Aviagen.com

Behnke, K. C. 1994. Factors affecting pellet quality. Maryland Nutr. Conf. Dept. of Poultry Science and Animal Science, College of Agriculture, University of Maryland, College Park.

Behnke, K. C. 1996. Feed manufacturing technology: Current issues and challenges. Anim. Feed Sci. Technol. 62:49-57.

Buchanan, N. P., K. G. S. Lilly, C. K. Gehring, and J. S. Moritz. 2008. The effect of diet formulation and manufacturing technique on pellet processing variables and quality. Poult. Sci. 87(Suppl. 1):166.(Abstr.)

Burkholder, J.M., and H.B. Glasgow, Jr. 1997. Pfiesteria piscicida and other Pfiesteria-like dinoflagellates: Behavior, impacts, and environmental controls. Limnol. Oceanogr. 42:1052-1075.

Carlos, L. 2005. High temperature air/steam gasification of biomass in an updraft fixed batch type gasifier. Ph.D. thesis. Royal Institute of Technology, Energy Furnace and Technology, Stockholm, Sweden.

Carpenter, S.R., N.F. Caraco, D.L. Correll, R.W. Howarth, A.N. Sharpley, and V.H. Smith. 1998. Nonpoint pollution of surface waters with phosphorus and nitrogen. Ecol. Applic. 8:559-568.

Chopra S. and Jain A. 2007. A Review of Fixed Bed Gasification Systems for Biomass. Agricultural Engineering International: the CIGR Ejournal. Invited Overview No. 5. Vol. 9.

Codling E., Chaney R., and Sherwell J. 2002. Poultry Litter Ash as a Potential Phosphorus Source for Agricultural Crops. J. Environ. Qual. 31:954-961.

Cosgrove, D. J., and G. C. J. Irving. 1980. Inositol Phosphates: Their chemistry, Biochemistry and Physiology. Elsevier/ North Holland, Inc., New York.

Cramer, K. R., K. J. Wilson, J. S. Moritz, and R. S. Beyer. 2003. Effect of sorghum-based diets subjected to various manufacturing procedures on broiler performance. J. Appl. Poult. Res. 12:404-410.

Cutlip, S. E., J. M. Hott, N. P. Buchanan, A. L. Rack, J. D. Latshaw and J. S. Moritz. 2008. The effect of steam conditioning practices on pellet quality and growing broiler nutritional value. J. App. Poult. Res. 17: $249-261$.

Davidson, S.G., J.G. Merwin, Jr., J. Capper, G. Power, and F.R. Shivers, Jr. 1997. Chesapeake waters: Four centuries of controversy, concern, and legislation. Tidewater Publ., Centreville, MD.

Eliasson, A. -C., K. Larsson, and Y. Miezis. 1981. On the possibility of modifying the gelatinization properties of starch by lipid surface coating. Starch/Stärke. 33:231-235.

Gardner, R.H., M.S. Castro, R.P. Morgan, and S.W. Seagle. 1996. Perspectives on Chesapeake Bay: Nitrogen dynamics in forested lands of the Chesapeake Basin. Chesapeake Research Consortium, Edgewater, MD. 
Gehring, C. K., K. G. S. Lilly, and J. S. Moritz. 2009a. Maximizing the performance of broilers fed pelleted diets. Multi-State Poultry Feeding and Nutrition Conference. May 19-21, Indianapolis, IN.

Graf, E. 1986. Chemistry and applications of phytic acid: an

overview. Phytic Acid: Chemistry and Applications, E. Graf, ed. Pilatus Press, Minneapolis, MN. 173194.

Grattan, L.M., D. Oldach, T.M. Perl, M.H. Lowitt, D.L. Matuszak, C. Dickson, C. Parrott, R.C. Shoemaker, C.L. Kaufman,M.P.Wasserman, J.R. Hebel, P. Charache, and J.G. Morris, Jr. 1998. Learning and memory difficulties after environmental exposure to water ways containing toxin-producing Pfiesteria or Pfiesteria-like dinoflagellates. Lancet 352:532-539.

Greiner, R., U. Konietzny, and K. D. Jany 1993. Purification and characterization of two phytases from Escherichia coli. Arch. Biochem. Biophys. 303:107-113.

Jaworski, N.A. 1990. Retrospective of the water quality issues of the upper Potomac estuary. Aqua. Sci. 3:11-40.

Lilly, K. G. S., C. K. Gehring, K. R. Beaman, and J. S. Moritz. 2009. Evaluating the effects of pellet quality on broiler performance and carcass yield. Poult. Sci. 88(Suppl. 1):(Accepted Abstract).

Lott, J. N. A. 1984. Accumulation of seed reserves of phosphorus and other minerals. Seed Physiology 1: 139-166.

Nayini, N. R., and P. Markakis. 1986. Phytases. Phytic Acid: Chemistry and Applications. E. Graf, ed. Pilatus Press, Minneapolis, MN. 101-118.

Nelson, T. S. 1976. The hydrolysis of phytin phosphorus by chicks and laying hens. Poult. Sci. 55:22622264.

Nelson, T. S., L. B. Daniels, J. R. Hall, and L. G. Shields. 1976. Hydrolysis of natural phytate phosphorus in the digestive tract of calves. J. Anim. Sci. 42:1509-1512.

Nixon, S.W. 1995. Coastal marine eutrophication: A definition, social causes, and future concerns. Ophelia 41:199-219.

O'Dell, B. L., and A. R. De Boland. 1976. Complexation of phytin with proteins and cations in corn germ and oilseed meals. J. Agric. Food Chem. 24:804-808.

Pallauf, J., and G. Rimbach. 1997. Effect of supplemental phytase on mineral and trace element bioavailability and heavy metal accumulation in pigs with different type diets. Phytase in Animal Nutrition and Waste Management. M. B. Coehlbo and E. T. Kornegay,ed. BASF Publication DC9601. BASF Corporation, Mount Olive, NJ.

Pasamontes, L., M. Haiker, M. Wyss, M. Tessier, and A. P. G. M. van Loon. 1997. Gene cloning, purification, and characterization of a heat-stable phytase from the fungus Aspergillus fumigatus. Appl. Environ. Microbiol. 63:1696-1700.

Phillippy, B. Q., M. R. Johnston, S. H. Tao, and M. R. S. Fox. 1988. Inositol phosphates in processed foods. J. Food Sci. 53:496-499. 
Pointillart, A., 1993. Importance of phytates and cereal phytases in the feeding of pigs. Pages 192-198 in Enzymes in Animal Nutrition. C Wenk, ed. ETH-Zurich, Zurich.

Ravindran, V., W. L. Bryden, and E. T. Kornegay. 1995. Phytin: Occurrence, bioavailability and implications in poultry nutrition. Poult. Avian Biol. Rev. 6:125-143.

Reddy, N. R., S. K. Sathe, and D. K. Saunkhe. 1982. Phytates in legumes and cereals. Adv. Food Res. 28:1-92.

Reed, T. B. and A. Das. 1988. Handbook of biomass downdraft gasifier engine systems. Colorado: Solar Energy Research Institute.

Reimer, L. 1992. Conditioning. In: Proc. Northern Crops Institute Feed Mill Management and Feed Manufacturing Technol. Short Course. p. 7. California Pellet Mill Co. Crawfordsville, IN.

Sharpley, A.M. 1995. Dependence of runoff phosphorus on extractable soil phosphorus. J. Environ. Qual. 24:920-926.

Staver, K.W., andR.B.Brinsfield. 1995b.The effects of erosion control practices on phosphorus transport from Coastal Plain agricultural watersheds. p. 215-222. In Proc. 1994 Chesapeake Bay Res. Conf. Chesapeake Research Consortium Publ. no. 149. Chesapeake Res. Consortium, Edgewater, MD.

Thomas, M., D. J. van Zuilichem, and A. F. B. Van der Poel. 1997. Physical quality of pelleted animal feed. 2. Contribution of processes and its conditions. Anim. Feed Sci. Tech. 64:173-192.

Thomas, M., T. van Vliet, and A. F. B. Van der Poel. 1998. Physical quality of pelleted animal feed. 1. Contribution of feedstuff components. Anim. Feed Sci. Tech. 70:59-78.

Thompson, L. U. 1986. Phytic acid: a factor influencing starch digestibility and blood glucose response. Phytic Acid: Chemistry and Applications. E. Graf, ed. Pilatus Press, Minneapolis, MN. 173-194.

USDA. 2009. National Agricultural Statistics Service. USDA.gov

Viveros, A., C. Centeno, A. Brenes, R. Canales, and A. Lozano. 2000. Phytase and acid phosphatase activities in plant feedstuffs. J. Agric. Food Chem. 48:4009-4013.

Wodzinski, R. J., and A. H. J. Ullah. 1996. Phytase. Advances in Applied Microbiology. 42: 263-302.

Zimonja, O., A. Stevnebø, and B. Svihus. 2007. Nutritional value of diets for broiler chickens as affected by fat source, amylose level and diet processing. Can. J. Anim. Sci. 87:553-562. 
IN VITRO TESTING OF PHYTASE RETENTION POST-PELLETING MAY NOT ADEQUATELY PREDICT EFFICACY

S. A. Loop ${ }^{1}$, L. K. Shires, C. K. Gehring, K. R. Beaman, and J. S. Moritz Division of Animal and Nutritional Sciences, West Virginia University, Morgantown, West Virginia, 26506-6108

Phone: 304-293-2631

Fax: 304-293-2232 


\section{SUMMARY}

Most commercially produced broilers consume pelleted feed that contains an exogenous phytase. Mixer added phytases are subjected to pelleting stress and, therefore, may be denatured. Companies have developed various techniques to prevent denaturation of phytase due to the pelleting process. However, there remains the potential for heat stable phytase to survive the pelleting process but lose efficacy in liberating phytate bound phosphorus in vivo. Dietary treatments of the current study consisted of positive and negative control formulations, differing in non-phytate phosphorus (NPP), as well as negative control formulations containing one of nine genetic variants of an E. coli derived mixer added phytase. All diets were steam conditioned at 71,77 , and $82^{\circ} \mathrm{C}$ prior to pelleting. Feed samples were analyzed for phytase pre and post-pelleting by a commercial laboratory to determine retention. The $77^{\circ} \mathrm{C}$ pellets were chosen for further evaluation via feeding experiment due to all 9 enzymes demonstrating high retention under those conditions, i.e. $60 \%$ or greater retention. Diets were fed to male, Cobb 500 broilers from d3 to 21. Feed intake, feed conversion ratio, live weight gain, tibia breaking strength, and tibia ash were calculated. Seven out of nine enzymes showed similar live weight gain to that of the positive control $(\mathrm{P}>0.05)$. Five of those enzymes demonstrated decreased feed conversion ratio of eight points on average compared to the other two $(\mathrm{P}=0.0102)$. Tibia breaking strength and tibia ash followed feed conversion trends; however, illustrated further differences among the five enzymes that demonstrated low feed conversion ratio $(\mathrm{P}<0.05)$. Evaluations of phytase must include in vivo animal testing beyond in vitro retention assays in order to fully assess efficacy.

\section{DESCRIPTION OF THE PROBLEM}

Phytase can be added to diets to liberate the phytate bound phosphorus already present in ingredients. Phytase products can either be incorporated into the diets by adding them directly to the mixer or by postpellet application. Most broilers consume pelleted feed that must be steam conditioned, extruded through a die, and dried. During this process mixer-added phytase may be denatured due to exposure to heat, moisture, and pressure. Phytase manufacturers have addressed this concern by using carbohydrate/lipid 
coatings, selecting phytase sources that are naturally heat stable, or genetic modification. Regardless, heat stable phytase must survive the pelleting process and also maintain function in the animal. Some phytase companies rely only on in vitro retention assays to determine enzyme retention post-pelleting and do not conduct concurrent in vivo feeding studies. Without subsequent feeding studies, the efficacy of phytase enzymes may not be properly be determined. The objective of this study was to test the validity of in vitro retention assays against in vivo feeding trials of nine different genetic variants of an E. coli derived phytase.

\section{MATERIALS AND METHODS}

The study consisted of two experiments; feed manufacture and live bird performance. Feed manufacture and subsequent feeding occurred during the fall and winter of 2008, using West Virginia University's pilot feedmill and poultry research facility respectively.

\section{Feed Manufacture}

Treatments consisted of positive and negative control diet formulations (PC,NC), differing in non-phytate phosphurs, as well as nine different genetically modified, E. coli derived, phytase enzymes (1) top dressed on the negative control formulation. Positive and negative control diets were formulated to be as similar as possible with respect to ingredient inclusion, while keeping the values for metabolizable energy, methionine and cysteine, lysine, and calcium the same. Soybean oil was included at $3 \%$ at the mixer to aid in enzyme retention (2). Adjustment in NPP level was the main difference between the calculated nutrients of the PC and NC formulations. The NPP levels were formulated to be $0.45 \%$ and $0.32 \%$ for the positive and negative control, respectively (Table 1). The NC diet and diets containing enzymes were made using a total of $4762.8 \mathrm{~kg}$ of feed. Six batches of $793.8 \mathrm{~kg}$ were made using the NC formulation. Each batch of $793.8 \mathrm{~kg}$ was then split into 10 allotments. Allotments from each batch were combined to create nutritionally uniform diets to be pelleted. The positive control diet consisted of one $476.28 \mathrm{~kg}$ batch. Prior to pelleting, each enzyme was added to the negative control per manufacturers specifications. Mixing was accomplished by adding enzyme to $2 \mathrm{~kg}$ of feed from one bag of each treatment in a small 
paddle mixer for five minutes. This mixture was then added back to the same bag prior to final mixing. Diets were all mixed for 12 minutes in a single screw vertical mixer before conditioning and pelleting (3). The order of the diets to be pelleted was selected at random with exception for the positive and negative treatments that were purposely chosen to be first. Treatments were steam conditioned in a sequential manner, i.e. $71,77,82^{\circ} \mathrm{C}$ using a short term conditioner. Pellets were formed using a California Pellet Mill (4) equipped with a $38 \mathrm{~mm}$ X $4.8 \mathrm{~mm}$ pellet die. Production rate was set at approximately one tonne per hour. Once study-state conditioning temperature was obtained and the desired amount of feed was collected, the temperature was increased to the next conditioning temperature and the process was repeated. Feed samples were collected for dry matter analysis at several stages in the pelleting process. Sampling occurred before steam conditioning (mash), after conditioning (hot pellet), cool pellet (directly off of the cooler belt), one hour post pelleting, and 3,6, and 9 days post pelleting. Pellet durability index (PDI) and modified pellet durability index (MPDI) were performed on all treatments one day after pelleting (5). After pelleting, bags were stored in a climate controlled room until the day of feeding to prevent excessive moisture migration. The climate conditions were maintained by heating the room to approximately $27^{\circ} \mathrm{C}$ as well as using a dehumidifier to remove excess moisture in the air. Mash and cooled pellet samples were sent to a commercial lab (6) to determine phytase retention using two different methodologies. Feed manufacture was not replicated therefore results should be interpreted as descriptive data.

\section{Live Bird Performance}

A total of 462, day old, male, Cobb 500 (7) chicks from a commercial hatchery (8) were fed the NC diet as a pretest in a floor pen setting. On d3, 440 of these chicks were selected based on weight to create uniformity in initial pen weight. Diets were randomly assigned to pens of 5 chicks. Groups of eleven adjacent pens were used as blocking criterion. Enzyme retention results showed that the diets conditioned at $77^{\circ} \mathrm{C}$ represented the highest conditioning temperature with the most consistent enzyme retention, therefore only pellets at this temperature were used in the live chick performance study. Treatments were replicated 8 times using a pen of chicks as the experimental unit. Chicks were housed in raised wire 
cages in a cross-ventilated, negative pressure room. Temperature and ventilation were monitored and altered to create optimal rearing conditions. Temperature on $\mathrm{d} 3$ was maintained at approximately $32^{\circ} \mathrm{C}$ $\left(90^{\circ} \mathrm{F}\right)$ and decreased to $29^{\circ} \mathrm{C}\left(85^{\circ} \mathrm{F}\right)$ during week 2 and to $26^{\circ} \mathrm{C}\left(80^{\circ} \mathrm{F}\right)$ during week 3. Pelleted feed, supplied in external troughs, and water, supplied through nipple drinkers, was provided for ad libitum consumption. Nipple drinkers were adjusted by visual inspection to appropriate height throughout the experiment. Chicks were exposed to continuous light throughout the study. On d21, chicks were killed via cervical dislocation and weighed on a per pen basis. Right tibias were extracted and frozen to perform tibia breaking strength as well as bone ash testing(9). Tibia breaking strength was determined using the Stable Micro Systems Texture Analyser (10), model TA-XT2i, fitted with a 3-point bend rig with a load cell capacity of $25 \mathrm{~kg}$ and a cross-head speed of $5 \mathrm{~mm} / \mathrm{sec}$. The three point bend test was utilized to test the force in $\mathrm{kg}$ needed to break the bone. Live weight gain (LWG), feed intake, and feed conversion ratio (FCR), using mortality weight, were calculated.

\section{Statistical Analysis}

Data was analyzed using one-way analysis of variance using SAS software (11). Significant differences were determined based on $\alpha \leq 0.05$. Means were separated using Fischer's least significant difference test. Scheffe's test was utilized when analyzing FCR to further demonstrate treatment differences among groups of treatments with similar responses since contrasts were not pre-planned.

\section{RESULTS AND DISCUSSION}

\section{Enzyme Retention}

Each enzyme retention was calculated using the amount of phytase in the unconditioned mash minus the amount of phytase in the cooled pellets, multiplied by 100. Enzyme retention was first tested using a version of the AOAC 2000.12 method modified for this specific phytase (12) (Figure 1). This method resulted in phytase levels in mash ranging from approximately 400 to $900 \mathrm{FTU}$. In respect to the $82^{\circ} \mathrm{C}$ treatments, enzyme $1,2,5,6,7,8$, and 9 retentions drop off numerically compared to the $77^{\circ} \mathrm{C}$ treatments. This could be due to denaturation of the enzyme associated with greater temperature and moisture of the 
$82^{\circ} \mathrm{C}$ treatment (Table 2). In respect to the $77^{\circ} \mathrm{C}$ treatments, enzymes $1,4,5,6,7$, and 9 had retention values that approximated 100 percent. The second method used to access enzyme retention was the standard AOAC 2000.12 method (13). This method resulted in phytase levels in mash ranging from approximately 300 to 900 FTU. This method was used to verify the AOAC 2000.12 modified test for pellets conditioned at $77^{\circ} \mathrm{C}$. Replicated data obtained using this method is shown in Figure 2. The AOAC 2000.12 method supports data obtained by the AOAC 2000.12 modified method in that enzyme retention among all 9 enzymes is arguably consistent. The modified AOAC method assay data showed average enzyme retention was the highest for enzyme 1 at $80.32 \%$, enzyme 4 at $82.36 \%$, and enzyme 2 at $79.01 \%$. Both methods used to assess enzyme retention show that enzyme 1 had consistently high retention in vitro.

\section{Feed Manufacture}

Pellets steam conditioned at higher temperatures had higher retained moisture directly following extrusion (Table 2). Pellet retained moisture was greatest directly following conditioning and extrusion and decreased approximately $3 \%$ by 9 days post manufacture (data not shown). Pellet durability index showed that pellets steam conditioned at $82^{\circ} \mathrm{C}$ had the highest PDI and MPDI, followed by the $77^{\circ} \mathrm{C}$, and $71^{\circ} \mathrm{C}$ steam conditioned pellets, respectively (Table 3). These trends in moisture retention and pellet quality are likely associated with increased starch gelatinization and protein gelation (14).

\section{Live Bird Performance}

Beginning pen weight was taken on d3. No significant differences were detected, indicating that all pens started at a similar weight. After the 3-21d experimental period and subsequent necropsy, significant differences were obtained for LWG $(\mathrm{P}=0.007)$, tibia breaking strength $(\mathrm{P}<0.001)$, and tibia ash $(\mathrm{P}<0.0001)$ among broilers fed the PC and NC formulations. Data from LWG showed that enzymes 2,3,5,6,7,8, and 9 had similar live weight gains to the positive control $(\mathrm{P}<0.05$, Figure 3$)$. When analyzing FCR among treatments with LWG similar to the positive control, there were no multiple comparison differences. However, numerical trends were observed when interoperating this data. Therefore, Scheffe's test was conducted and showed that enzymes 5,6,7,8, and 9 had a significant 
reduction in FCR $(\mathrm{P}<0.0102)$ compared to enzymes 2 and 3 (Figure 4). Tibia breaking strength (Figure 5) and tibia ash (Figure 6) showed that enzyme 9 had a significantly higher breaking strength $(\mathrm{P}<0.0001)$ and tibia ash $(\mathrm{P}<0.0001)$ than the positive control, indicating that the bone was better mineralized. Enzyme 1 had the lowest values for LWG, tibia breaking strength, and tibia ash despite its high retention values in vitro.

\section{CONCLUSIONS AND APPLICATIONS}

1. Genetic variants of an E. coli derived phytase added at the mixer may have decreased retention due to conditions of high heat and moisture associated with steam conditioning.

2. Phytase enzyme efficacy should be based on several in vivo parameters instead of only in vitro retention assays. 


\section{REFRENCES}

1. Syngenta Corporation, Wilmington, DE

2. Gehring, C.K, Lilly, K.G.S., Shires, L.K., Beaman, K.R., Loop, S.A., Moritz, J.S., Increasing mixer-added fat reduces the electrical energy required for pelleting and improves exogenous enzyme efficacy for broilers.

3. Weigh-Tronix single-screw vertical mixer with a 1-ton capacity.

4. California Pellet Mills Inc., Crawfordsville, IN.

5. American Society for Agricultural Engineers, 1983. Methods for determining and expressing fineness of feed materials by sieving. Page 325 in American Society of Agricultural Engineers Standard S 319. Am. Soc. Agric. Eng. Yearbook Standards, Am. Soc. Am. Eng., St. Joseph, MI. Pellet durability index was determined by sifting $500 \mathrm{~g}$ of pellets from a treatment through a No. 6 American Society for Testing and Materials (ASTM) screen before being deposited into a Pfost tumbler. The sifted pellets were then tumbled in the container, dimensions $5 \times 12 \times$ 12 in., with a $2 \times 9$ in. plate fixed diagonally along the $12 \times 12$ in. side, for approximately $10 \mathrm{~min}$ at $50 \mathrm{rpm}$. The sample was then sifted again through the No. 6 (ASTM) mm screen, weighed, and the percentage of pellets was calculated by dividing the weight of pellets after tumbling by the weight of pellets before tumbling and then multiplying that value by 100 . Modified pellet durability index was similarly measured, with the exception of the addition of five, $13-\mathrm{mm}$ hexagonal bolts to the $500 \mathrm{~g}$ of sample in the tumbler. Both analyses are meant to simulate the deleterious effects of transferring and handling the pellets.

6. Eurofins Scientific, Des Moines, IA

7. Cobb-Vantress, Siloam Springs, AR

8. Matterns Hatchery, Beaver Springs, PA

9. After bone breaking strength tests, all pieces of bone were collected. Bones were weighed then placed in a $600^{\circ} \mathrm{C}$ ashing oven overnight.

10. Stable Micro Systems Ltd., Surrey, UK

11. SAS Institute. 2000. The SAS System for Windows

12. AOAC 2000.12 Modified

13. AOAC. 2000. Method 2000.12: Phytase activity in feed: Colorimetric enzymatic method. In Official Methods of Analysis of AOAC International. 17th ed. Assoc. Off. Anal. Chem., Arlington, VA.

14 . Moritz, J. S., K. R. Cramer, K. J. Wilson, and R. S. Beyer. 2003.

Feed manufacture and feeding of rations with graded levels of added moisture formulated to different energy densities. J. Appl.

Poult. Res. 12:371-381. 
Table 1. Diet formulations

\begin{tabular}{|c|c|c|}
\hline Ingredients & Positive Control & Negative Control \\
\hline Corn & $\%$ & 54.16 \\
\hline Soybean Meal (44\%) & 54.09 & 33.99 \\
\hline $\begin{array}{c}\text { Corn Distillers Grains and } \\
\text { Solubles }\end{array}$ & 33.88 & 5.00 \\
\hline Soybean Oil & 5.00 & 3.00 \\
\hline Limestone & 3.00 & 1.08 \\
\hline Porcine Meat and Bone Meal & 0.55 & 0.83 \\
\hline Defloronated Phosphorus & 0.93 & 0.68 \\
\hline Methionine & 1.38 & 0.31 \\
\hline Salt & 0.31 & 0.28 \\
\hline NB 3000 & 0.20 & 0.25 \\
\hline Lysine & 0.25 & 0.25 \\
\hline Coban 60 & 0.25 & 0.08 \\
\hline Threonine & 0.08 & 0.06 \\
\hline BMD & 0.06 & 0.05 \\
\hline ME (kcal/lb) & 0.05 & 1394 \\
\hline Meth + Cyst (\%) & Calculated Nutrient Analysis \\
\hline Lysine (\%) & 1394 & 0.98 \\
\hline Calcium (\%) & 0.98 & 1.28 \\
\hline Non-Phytate Phosphorus (\%) & 1.28 & 0.91 \\
\hline kg & 0.91 & 0.32 \\
\hline
\end{tabular}

${ }^{\mathrm{A}}$ Supplied per kg of diet: manganese, $0.02 \%$; zinc $0.02 \%$; iron, $0.01 \%$; copper, $0.0025 \%$; iodine, $0.0003 \%$; selenium, $0.00003 \%$; folic acid, $0.69 \mathrm{mg}$; choline, 386mg' riboflavin, $6.61 \mathrm{mg}$; biotin, $0.03 \mathrm{mg}$; vitamin $\mathrm{B}_{6}, 1.38 \mathrm{mg}$; niacin, 27.56mg; pantothenic acid, $6.61 \mathrm{mg}$; thiamine, $2.20 \mathrm{mg}$; manadione, $0.83 \mathrm{mg}$; vitamin $\mathrm{B}_{12}, 0.01 \mathrm{mg}$; vitamin E, $16.53 \mathrm{IU}$; vitamin $\mathrm{D}_{3}, 2133 \mathrm{ICU}$; vitamin $\mathrm{A}, 7716 \mathrm{IU}$.

${ }^{\mathrm{B}}$ Active drug ingredient Monensin Sodium $60 \mathrm{gpb}$ ( $90 \mathrm{~g} / \mathrm{ton}$ inclusion), Elanco Animal Health, Indianapolis, IN. As an aid in the prevention of coccidiosis caused by Eimeria necarix, Eimeria tenella, Eimeria acervulina, Eimeria brunette, Eimeriamivati, and Eimeria maxima.

${ }^{\mathrm{C}}$ Bacitracin Methylene Disalicylate $50 \mathrm{~g} / \mathrm{lb}$ (50 g/ton inclusion), Alpharma, Fort Lee, NJ. For increased rate of weight gain and improved feed efficiency. 
Figure 1. Phytase enzyme retention of pellets conditioned at $71^{\circ} \mathrm{C}, 77^{\circ} \mathrm{C}$, and $82^{\circ} \mathrm{C}$ using the AOAC 2000.12 method modified for the specific phytase tested

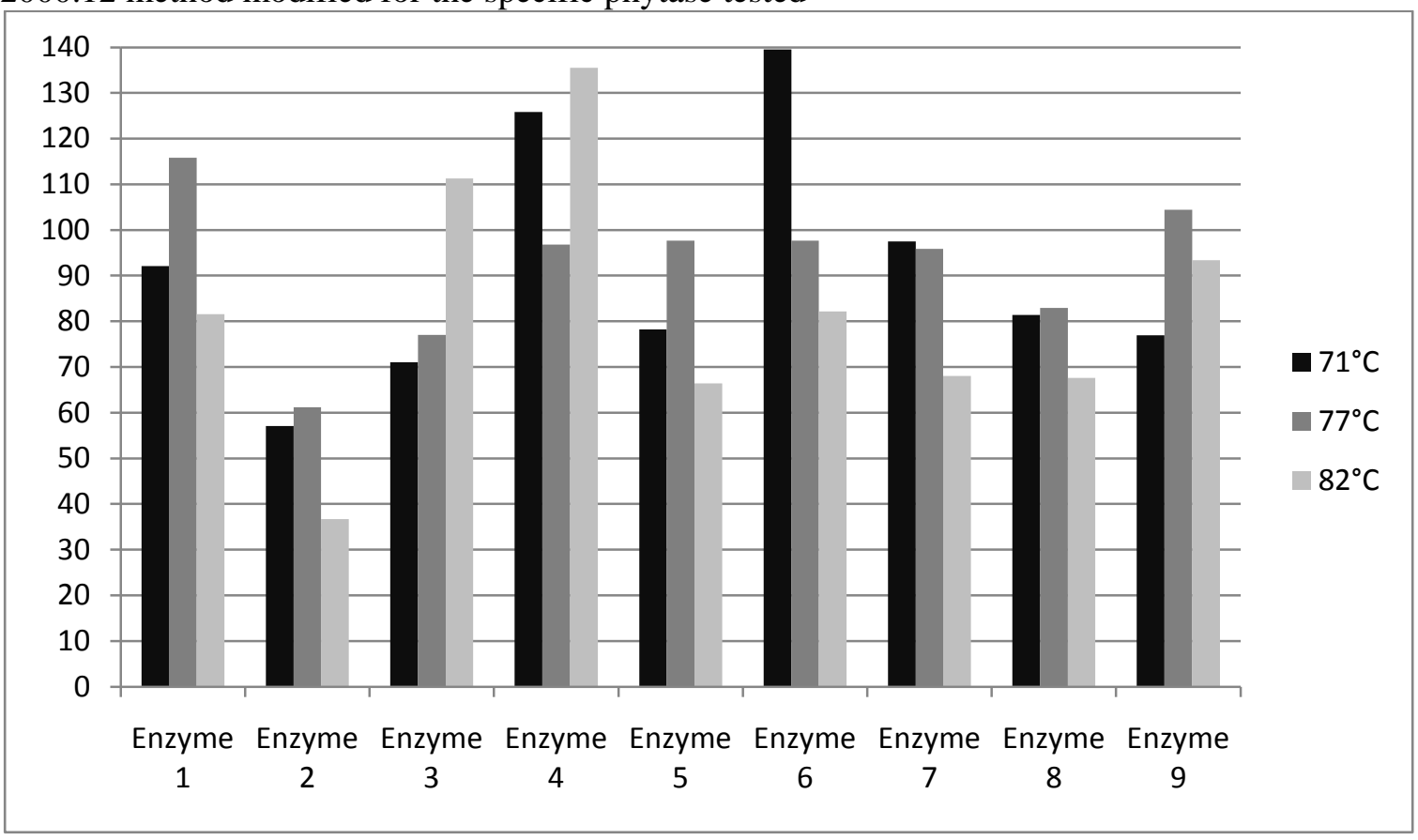

Table 2. Percent moisture of pellet samples taken directly off the cooler belt. Pellets were conditioned at 71,77 , and $82^{\circ} \mathrm{C}$.

\begin{tabular}{|c|c|c|c|}
\hline \multirow{2}{*}{ Treatment } & \multicolumn{3}{|c|}{ Conditioning Temperatures } \\
\cline { 2 - 4 } & $71^{\circ} \mathrm{C}$ & $77^{\circ} \mathrm{C}$ & $82^{\circ} \mathrm{C}$ \\
\hline Positive Control & 13.9 & 15.2 & 16.2 \\
\hline Negative Control & 15.1 & 15.0 & 15.6 \\
\hline Enzyme 1 & 15.2 & 15.3 & 15.9 \\
\hline Enzyme 2 & 14.1 & 15.1 & 15.2 \\
\hline Enzyme 3 & 15.2 & 15.4 & 16.3 \\
\hline Enzyme 4 & 14.0 & 15.1 & 16.5 \\
\hline Enzyme 5 & 15.2 & 15.8 & 16.0 \\
\hline Enzyme 6 & 14.5 & 15.0 & 15.3 \\
\hline Enzyme 7 & 14.4 & 14.4 & 15.4 \\
\hline Enzyme 8 & 13.8 & 14.0 & 14.4 \\
\hline Enzyme 9 & 13.8 & 14.5 & \\
\hline
\end{tabular}


Figure 2. Enzyme Retention of Pellets Conditioned at $77^{\circ} \mathrm{C}$ using the AOAC 2000.12 method

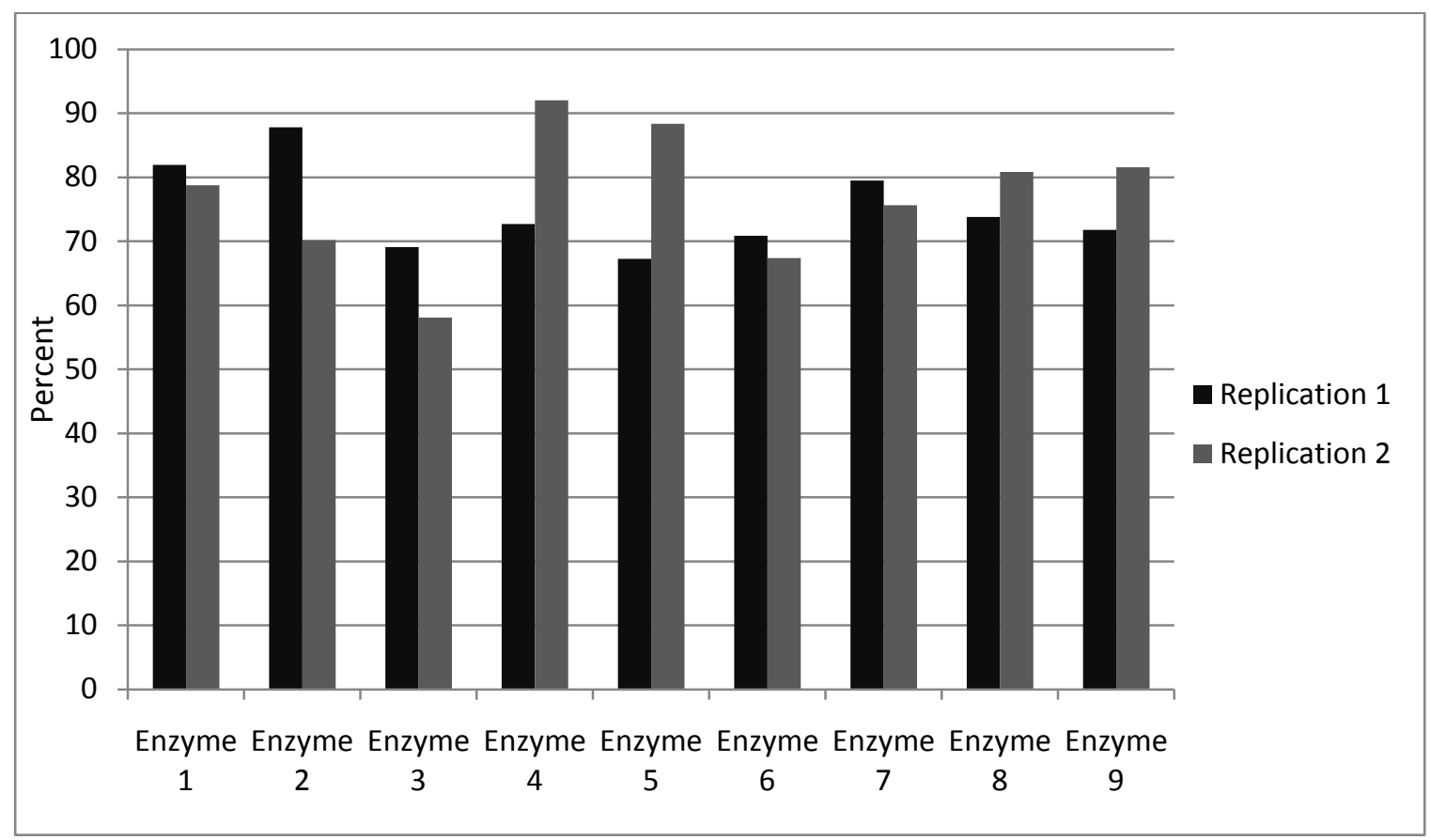

Table 3. Average pellet durability index (percent) of pellets conditioned at 71,77 , and $82^{\circ} \mathrm{C}$. Analysis was conducted 1 day post manufacture

\begin{tabular}{|c|c|c|c|}
\hline \multirow{2}{*}{ Treatment } & \multicolumn{3}{|c|}{ Conditioning Temperature } \\
\cline { 2 - 4 } & $71^{\circ} \mathrm{C}$ & $77^{\circ} \mathrm{C}$ & $82^{\circ} \mathrm{C}$ \\
\hline Positive Control & 73.09 & 72.07 & 74.41 \\
\hline Negative Control & 75.29 & 75.57 & 77.47 \\
\hline Enzyme 1 & 75.48 & 74.94 & 76.55 \\
\hline Enzyme 2 & 73.16 & 73.99 & 76.31 \\
\hline Enzyme 3 & 73.91 & 73.21 & 76.66 \\
\hline Enzyme 4 & 73.87 & 73.32 & 75.4 \\
\hline Enzyme 5 & 74.75 & 75.19 & 78.65 \\
\hline Enzyme 6 & 71.88 & 72.59 & 75.07 \\
\hline Enzyme 7 & 72.58 & 77.35 & 77.47 \\
\hline Enzyme 8 & 73.94 & 77.13 & 76.09 \\
\hline Enzyme 9 & 72.7 & 75.51 & 77.53 \\
\hline
\end{tabular}


Figure 3. The effect of $E$. coli derived phytase on live weight gain of chicks from d3-d21. Gray colored bars indicate treatments with LWG similar to the positive control.

${ }^{\mathrm{a}-\mathrm{e}}$ Means within a column without a common superscript differ significantly $(\mathrm{P} \leq 0.05)$.

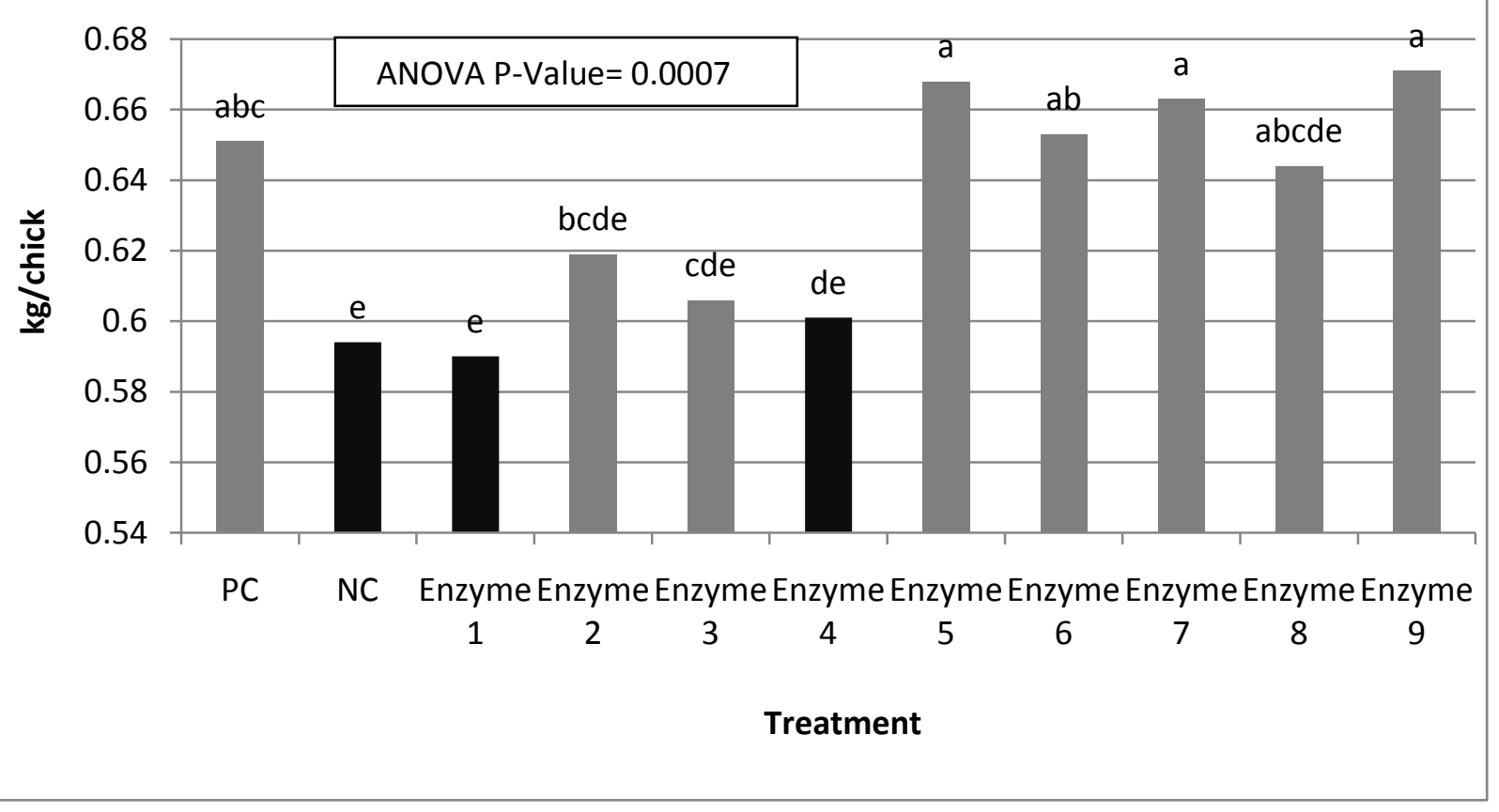


Figure 4. The effect of $E$. coli derived phytase on feed conversion ratio of chicks from d3-d21. Gray colored bars indicate treatments with LWG similar to the positive control. Numerical differences seen between enzymes with similar LWG prompted Scheffe's test. This test showed significant differences between treatments that had similar LWG. Scheffe's test was utilized since contrasts were not preplanned.

${ }^{\mathrm{a}-\mathrm{c}}$ Means within a column without a common superscript differ significantly $(\mathrm{P} \leq 0.05)$.

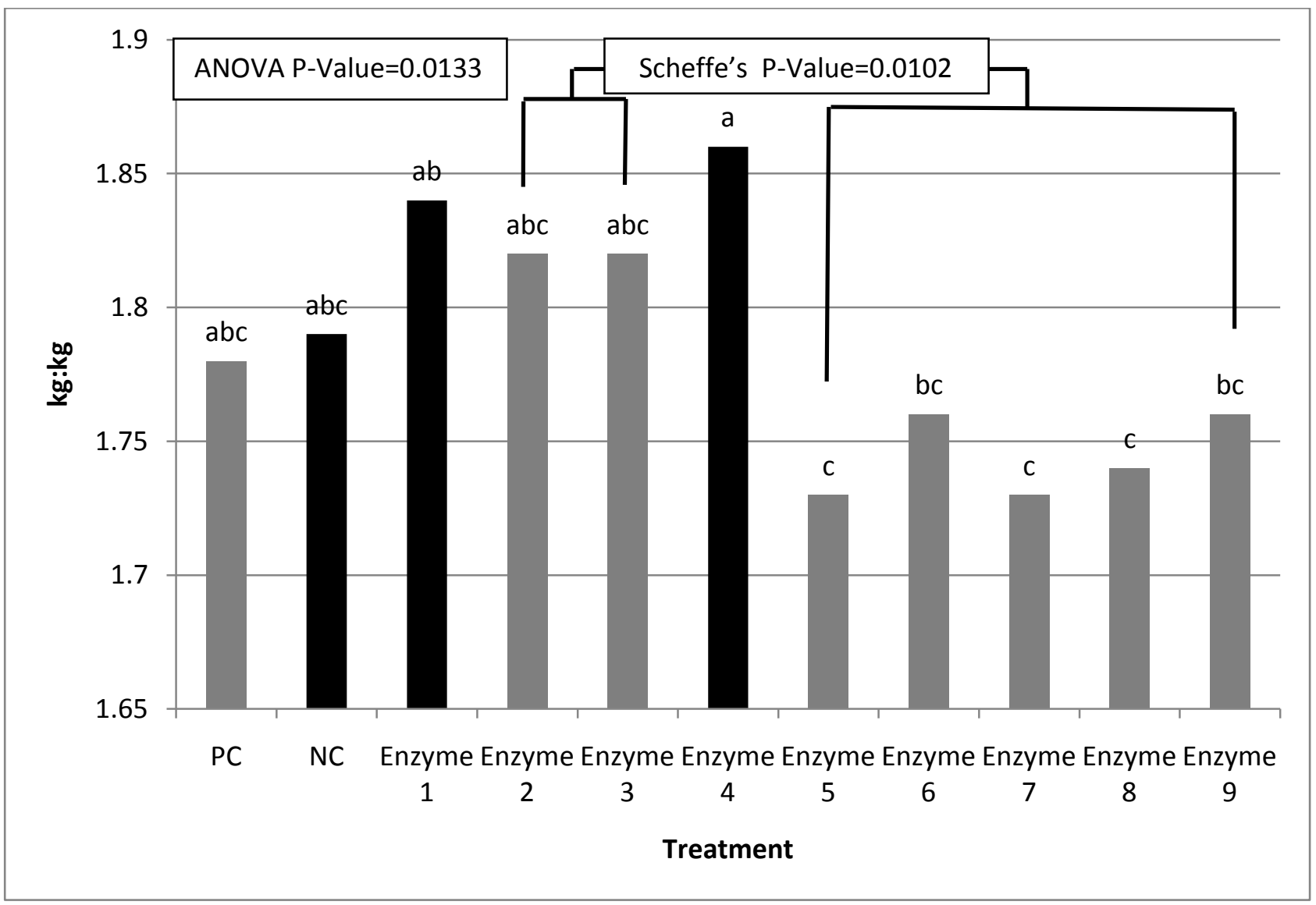


Figure 5. The effect of $E$. coli derived phytase on tibia breaking strength of chicks from d3-21. Gray colored bars indicate treatments with LWG similar to the positive control.

${ }^{\mathrm{a}-\mathrm{g}}$ Means within a column without a common superscript differ significantly $(\mathrm{P} \leq 0.05)$.

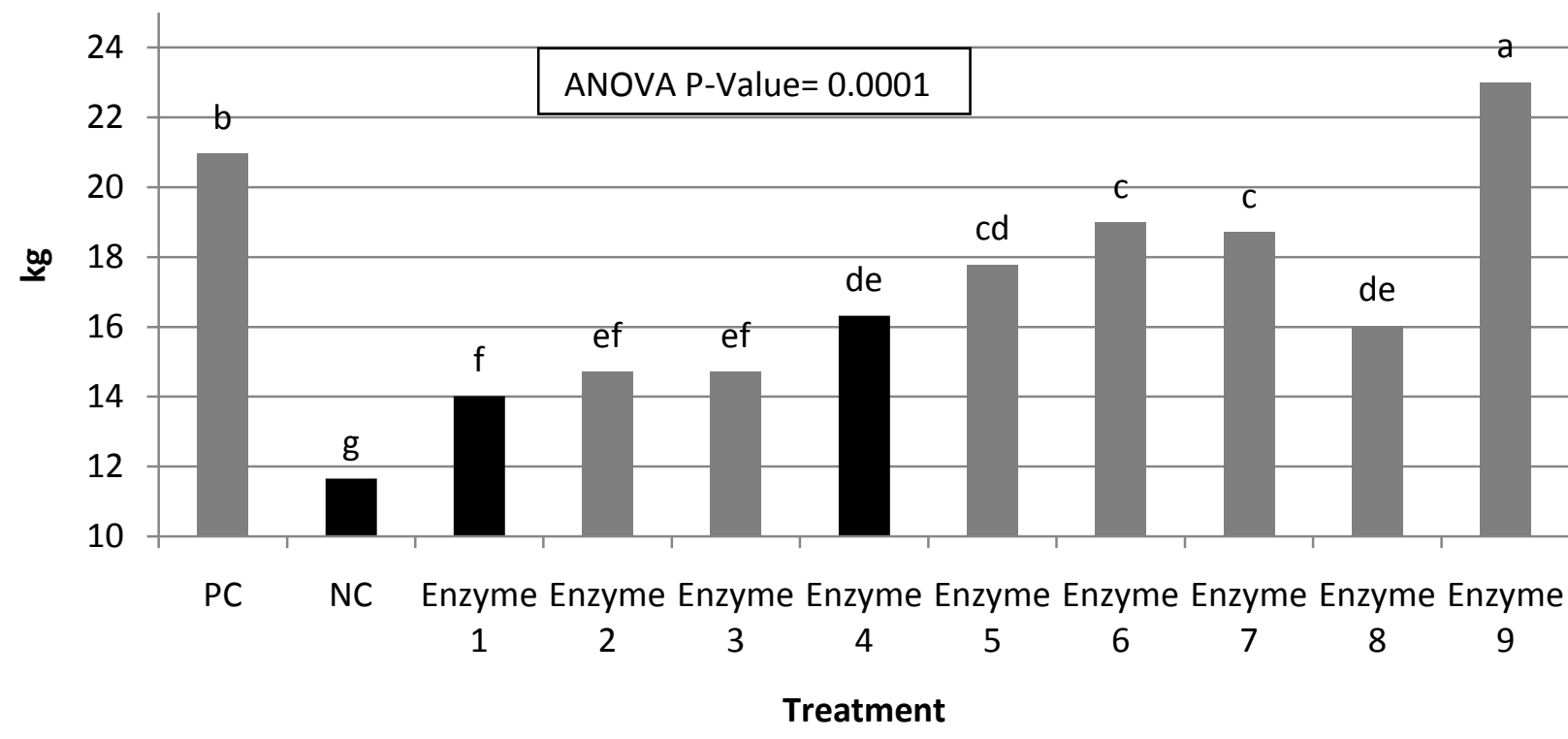

Figure 6. The effect of E. coli derived phytase on tibia ash of chicks from d3-21. Gray colored bars indicate treatments with LWG similar to the positive control.

${ }^{\mathrm{a}-\mathrm{g}}$ Means within a column without a common superscript differ significantly $(\mathrm{P} \leq 0.05)$.

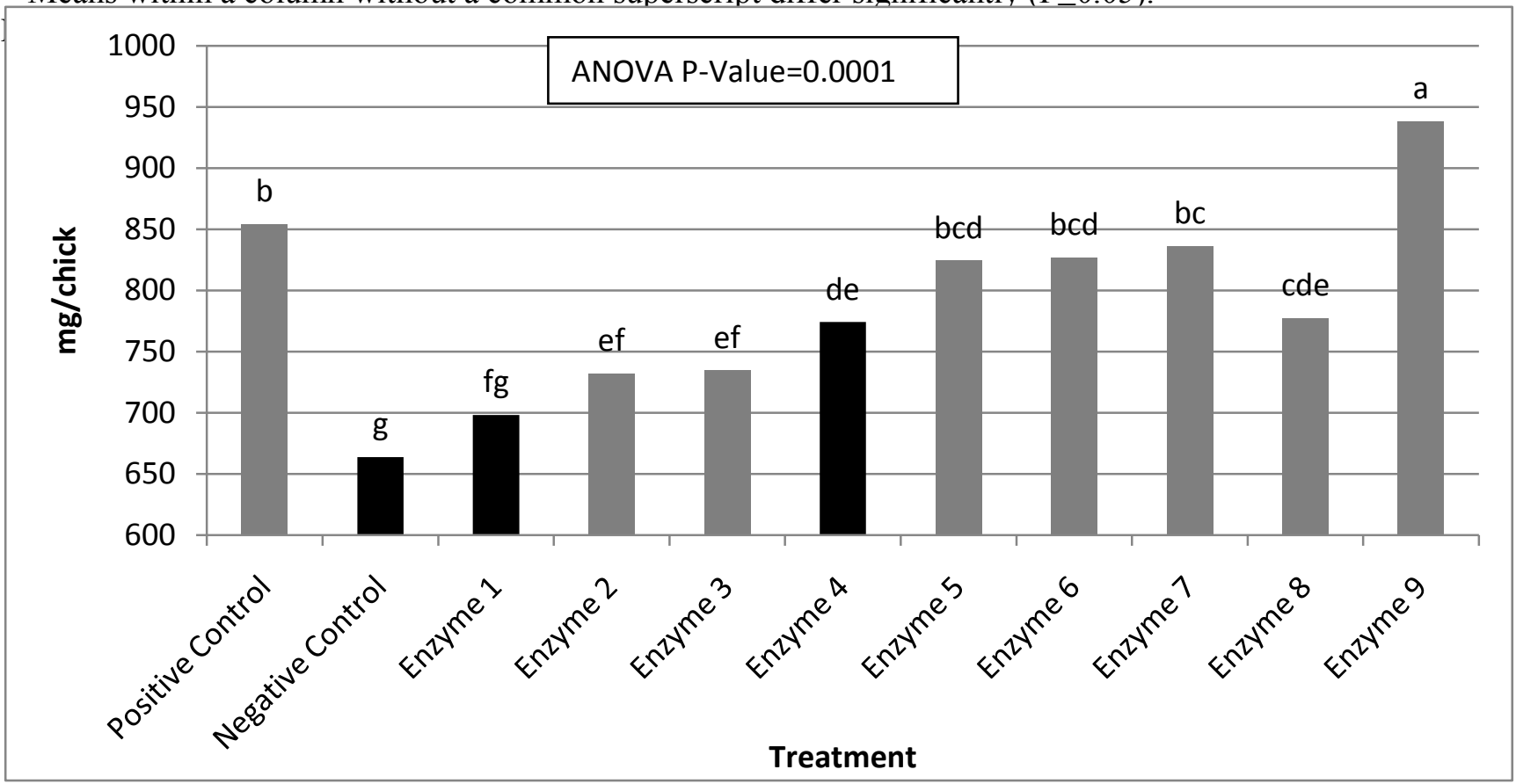


EVALUATION OF THE EFFECTS OF POULTRY LITTER ASH ON FEED MANUFACTURE AND PERFORMANCE VARIABLES IN BROILERS

S. A. Loop ${ }^{1}$, L. K. Shires, K.G.S Lilly, K. R. Beaman, B.L. West and J. S. Moritz Division of Animal and Nutritional Sciences, West Virginia University, Morgantown, West Virginia, 26506-6108

Phone: 304-293-2631

Fax: 304-293-2232 


\section{SUMMARY}

Phosphorus is an essential ingredient used when formulating broiler diets. It is imperative that chicks receive adequate amounts of phosphorus within the first three weeks of life. Rock phosphorus sources have been supplemented in broiler diets for many years and provide a source of phosphorus as well as calcium. Rock phosphorus is beneficial in feed manufacture as it has a die scouring effect which increases throughput of feed when pelleting. Rock phosphorus sources are nonrenewable and in high demand which causes the price of this ingredient to increase. The use of an alternative phosphorus source could slow the depletion of rock phosphorus as well as decrease feed cost. Poultry litter ash is a byproduct of poultry litter after the gasification process. Poultry litter ash contains phosphorus and calcium as well as other minerals. Dietary treatments in the current study consisted of seven different formulations. Four diets were formulated with varying levels of phosphorus and calcium to create a standard curve. Diet 5 was formulated to be similar to the PC with PLA to be compared to the standard curve. Diet 6 was formulated as a commercial diet. Diet 7 was formulated as a commercial diet with PLA. Feed manufacture and live bird production variables were calculated. Production rate data suggests that addition of PLA does not increase throughput compared to diet 4 (PC). PDI data suggests that diet 5 (PC with PLA) produced pellets of higher quality than the positive control. PLA showed no benefits to live bird performance variables due to possible antinutritive factors, however bone ash testing suggests some phosphorus and calcium in PLA is utilizable by the birds.

\section{DESCRIPTION OF THE PROBLEM}

Most commercially raised broilers consume a corn-soybean based diet. Approximately $2 / 3$ of the phosphorus in mature cereal grains is present as phytate bound phosphorus, which the bird is unable to use. Endogenous phytase enzymes are responsible for hydrolyzing phytate phosphorus into a usable form of phosphorus for the animal. However, non-ruminants do not produce enough phytase to liberate the amount of phosphorus needed to properly mineralize their rapidly growing bones. To combat this 
problem, rock phosphorus is added to the diets to increase the amount of utilizable phosphorus. However, increasing the amount of rock phosphorus in the diet is costly, increases the amount of phosphorus in the manure and consequent eutrophication of water sheds, and contributes to the global feed phosphorus shortage. This shortage is due to an exceptionally high demand for phosphorus containing fertilizers. Feed phosphates and fertilizers are both produced from a common raw material. The use of an alternative phosphorus source could help in slowing down the depletion of this resource as well as reduce the cost of phosphorus supplementation in broiler diets. Poultry litter ash (PLA) has shown promise as a phosphorus source in poultry nutrition (1). Poultry litter is subjected to a gasification process which heats the litter enough to produce an ash or char. During this process, the heat emitted may be used to heat the poultry houses. The PLA is heated to high enough temperatures to destroy pathogens, while retaining some essential minerals such as calcium, phosphorus, and sodium. Moreover, rock phosphorus sources have varying effects on pellet mill production rate, electrical energy use of the pellet mill, and pellet quality. All of these are important economic factors of feed manufacture. In addition to nutritional benefits, poultry litter ash may have the potential to enhance pellet production and quality.

\section{MATERIALS AND METHODS}

The study consisted of two experiments; feed manufacture and live bird performance. Feed manufacture and subsequent feeding occurred during the spring of 2010, using West Virginia University's pilot feedmill and poultry research facility, respectively.

\section{Feed Manufacture}

Prior to diet formulation, samples of PLA were sent to a commercial lab (2) for proximate analysis (Table 1), mineral content, and water-soluble phosphorus content (which is interoperated as non-phytate phosphorus)(Table 2). Using these values, seven diets were formulated (Table 3). Negative control (NC/diet 1) and positive control diets (PC/diet 4) were formulated to contain $0.23 \%$ and $0.45 \%$ nonphytate phosphorus (NPP), respectively. A standard curve consisting of four diets was used to create varying levels of NPP and calcium using the PC and NC. Diet 5 was formulated to be as similar to diet 4 as possible and contained $0.45 \%$ NPP and $0.91 \%$ calcium. These values were provided by substituting 
limestone, salt, and deflouronated phosphorus with PLA. Diet 6 was formulated as a commercial diet with a phytase enzyme but without PLA to compare among treatments. Diet 7 was formulated similarly, as a commercial diet, but contained PLA as well as a phytase enzyme to determine how PLA would work in a more commercial diet. Diets 1 through 4 were formulated to be as similar as possible with respect to ingredient inclusion, while keeping the values for metabolizable energy, methionine and cysteine, and lysine the same. Sand was utilized as a diluent in diets that did not contain PLA. Initially, diets 1 and 4 consisted of approximately $1179 \mathrm{~kg}$ each. All diets were mixed in batches of approximately $590 \mathrm{~kg}$ therefore, diets 1 and 4 were mixed in 2 batches. After batching, diet 2 was created by combining $408 \mathrm{~kg}$ of NC with $136 \mathrm{~kg}$ of PC. Diet 3 was created in the same fashion by combining $408 \mathrm{~kg}$ of PC with $136 \mathrm{~kg}$ of NC. All of diets 1 through 3 were pelleted on $\mathrm{d} 1$ as well as one run of diets 4 through 7 using $136 \mathrm{~kg}$ of each diet. A total of $533 \mathrm{~kg}$ of each diet were pelleted. On $\mathrm{d} 2$, the remaining three runs of diets 4 through 7 were pelleted in random order. Replication of diets 4 through 7 were conducted to determine milling data as well as pellet quality. Diets were steam conditioned at $77^{\circ} \mathrm{C}$. Pellets were formed using a California Pellet Mill (3) equipped with a 38mm X 4.8mm die. Production rate was approximately one tonne per hour. Cool pellet samples were taken after bagging to perform dry matter analysis. Pellet durability index (PDI) and modified pellet durability index (MPDI) were performed on all replicated treatments one day post-pelleting (4). Feed manufacture variables including conditioner and pellet mill relative electrical energy, production rate, and bulk density were calculated. Calcium and water-soluble phosphorus analyses were conducted on amalgamated cool pellet samples of each treatment.

\section{Live Bird Performance}

A total of 700 male and 700 female, Cobb 500 (5) chicks from a commercial hatchery (6) were fed the $\mathrm{NC}$ diet as a pretest in a floor pen setting. On d3, 616 females and 616 males were selected based on weight to create uniformity in initial pen weight. Chicks were randomly assigned to one of 7 dietary treatments. Groups of 7 pens were used as blocking criterion. Treatments were replicated 8 times using a pen of 11 males and 11 females as the experimental unit. Chicks were housed in 0.69 X $2.44 \mathrm{~m}$ floor

pens. A total of two rooms were used in a cross-ventilated, negative pressure house with forced air 
brooders. A woven wire barrier between the two rooms allowed for air exchange. Temperature and ventilation were monitored to maintain bird health. Temperature during week one was held at approximately $35^{\circ} \mathrm{C}$, and decreased to approximately $29^{\circ} \mathrm{C}$ in the weeks thereafter. Pelleted feed, supplied by hanging feed pans (7), and water, supplied by nipple drinkers (8), was provided for ad libitum consumption. Chicks were exposed to continuous light for the first week followed by 20 hours of light per day for the remaining two weeks. On d21, birds were weighed on a per pen basis. Five birds were selected from each pen that were within the range of 100 grams plus or minus the mean pen weight, regardless of sex. These birds were then killed via cervical dislocation and the left tibia was extracted for tibia ash testing (9). Feed intake, live weight gain (LWG), and feed conversion ratio (FCR) were calculated.

\section{Statistical Analysis}

Data was analyzed with one-way analysis of variance using SAS software (10). Significant differences were determined based on $\alpha \leq 0.05$. Means were separated using Fischer's least significant difference test.

\section{RESULTS AND DISCUSSION}

For simplification purposes diets 4 through 7 will be referred to as the following:

Diet 4- Positive control (PC)

Diet 5- PC with PLA

Diet 6-Commercial diet

Diet 7-Commercial diet with PLA

\section{Feed Manufacture}

Statistical analysis of feed manufacture data was only conducted on diets 4 through 7 . The design of the study was designed to compare the PC with PLA diet to the 4 diets in the standard curve, as well as compare the commercial with PLA diet to the commercial diet. Therefore, it should be noted that the following sections will focus mainly on those comparisons. Data showed no difference between all treatments with respect to conditioner relative electrical energy usage, however pellet mill relative electrical energy usage data showed the PC and PC with PLA diets to have statistically similar relative electrical energy usage. Both of these diets had lower relative electrical energy usage than both 
commercial diets (Figure 1). This decrease in pellet mill relative electrical energy usage could be due to the increased mixer added fat in the PC and PC with PLA diets(11). Production rate data suggests that addition of PLA does not increase throughput compared to the PC. However, production rate is not statistically different between the PC with PLA diet, commercial diet, and commercial with PLA diet (Figure 2). Bulk density data showed no multiple comparison differences. PDI data shows that the PC with PLA diet produced pellets of higher quality than the PC, suggesting that PLA may have a binding effect (Figure 3). In addition, the commercial diet and the commercial with PLA diet produced better quality pellets than the PC and PC with PLA diets. MPDI data (not shown) followed the same trend. Increased pellet quality of the commercial and commercial with PLA diets may be attributed to decreased mixer added fat (12). Prior to diet formulation, PLA samples were shown to contain approximately $11 \%$ fiber. This increase in fiber in the PLA may have contributed to increased pellet quality due to the effect of the particle binding in the pellets (13).

\section{Live Bird Performance}

Statistical differences were demonstrated between diet 1 (NC) and diet 4 (PC) for feed intake and LWG $(\mathrm{P} \leq 0.0001)$. Multiple comparison differences were also shown for diets 1 through 4 with respect to LWG and also showed similar trends for feed intake. These data points were indicative of the validity of the standard curve. Feed intake was significantly reduced in the PC with PLA diet when compared to the PC. However, feed intake of the chicks fed the commercial with PLA diet were statistically similar to the commercial diet (Figure 4). LWG was also reduced in chicks fed diets containing PLA with the commercial diet with PLA demonstrating LWG similar to the NC diet (Figure 5). LWG of birds fed the commercial diet was similar to LWG of birds fed diet 2, despite adequate nutrient levels. This could be due to the denaturation of amino acids during pelleting due to the low fat inclusion in the commercial diet (11). The PC with PLA diet, commercial diet, and commercial with PLA diet demonstrated increased FCR when compared to the positive control (Figure 6). Decreased feed intake of birds fed diets containing PLA could explain differences in FCR. The decreased performance of birds fed diets containing PLA could be caused by a number of factors. PLA is known to be alkaline (14) which could 
interfere with enzyme efficacy in the gastrointestinal tract of the birds. Also, PLA may interfere with gut viscosity, causing decreased absorption of nutrients (15). PLA may also contain levels of heavy metals that could cause adverse effects on performance (16). The levels of heavy metals in the PLA were determined by a commercial lab (17) and are shown in table 4. Bone ash testing demonstrated the PC plus PLA diet to have similar mineralization properties as diet 3 (Figure 7). With this data, PLA was calculated to contain $0.13 \%$ NPP, which validates the initial inclusion of PLA in the diets.

\section{CONCLUSIONS AND APPLICATIONS}

1. Poultry litter ash shows significant benefits to feed manufacture and pellet quality with respect to similar pellet mill relative electrical energy use as deflourinated phosphorus and increased PDI and MPDI.

2. Poultry litter ash has detrimental effects on production variables at the inclusion levels in this study, however, shows promise as an alternative source to rock phosphorus and contains $0.13 \%$ NPP. 


\section{REFERENCES}

1. Akpe, M.P., P.E. Waibel, and R.V. Morey. 1984. Bioavailability of phosphorus in poultry litter biomass ash residue for turkeys. Poultry Sci. 63:2100-2102.

2. New Jersey Feed Lab Inc, Trenton, NJ

3. California Pellet Mills Inc., Crawfordsville, IN.

4. American Society for Agricultural Engineers, 1983. Methods for determining and expressing fineness of feed materials by sieving. Page 325 in American Society of Agricultural Engineers Standard S 319. Am. Soc. Agric. Eng. Yearbook Standards, Am. Soc. Am. Eng., St. Joseph, MI. Pellet durability index was determined by sifting $500 \mathrm{~g}$ of pellets from a treatment through a No. 6 American Society for Testing and Materials (ASTM) screen before being deposited into a Pfost tumbler. The sifted pellets were then tumbled in the container, dimensions $5 \times 12 \times 12$ in., with a $2 \times 9$ in. plate fixed diagonally along the $12 \times 12 \mathrm{in}$. side, for approximately $10 \mathrm{~min}$ at $50 \mathrm{rpm}$. The sample was then sifted again through the No. 6 (ASTM) mm screen, weighed, and the percentage of pellets was calculated by dividing the weight of pellets after tumbling by the weight of pellets before tumbling and then multiplying that value by 100. Modified pellet durability index was similarly measured, with the exception of the addition of five, 13-mm hexagonal bolts to the $500 \mathrm{~g}$ of sample in the tumbler. Both analyses are meant to simulate the deleterious effects of transferring and handling the pellets.

5. Cobb-Vantress, Siloam Springs, AR

6. Matterns Hatchery, Beaver Springs, PA

7. Kuhl Corporation, Flemington, NJ.

8. Ziggity Systems Inc., Middlebury, IN.

9. Tibias were placed in a soxhlet apparatus with petroleum ether overnight. All fat-extracted bones were ashed in a $600^{\circ} \mathrm{C}$ ashing oven overnight.

10. SAS Institute. 2000. The SAS System for Windows

11. Gehring, C.K, Lilly, K.G.S., Shires, L.K., Beaman, K.R., Loop, S.A., Moritz, J.S., Increasing mixer-added fat reduces the electrical energy required for pelleting and improves exogenous enzyme efficacy for broilers. Unpublished data.

12. Gehring, C. K., K. G. S. Lilly, and J. S. Moritz. 2009. Maximizing the performance of broilers fed pelleted diets. Multi-State Poultry Feeding and Nutrition Conference. May 19-21, Indianapolis, IN. 
13. Thomas, M., T. van Vliet, A. F. B. van der Poel. 1998. Physical quality of pelleted animal feed 3. Contribution of feedstuff components. Anim. Feed. Sci. Technol. 70:59-78.

14. Codling, E., Chaney, R., and Sherwell, J. 2002. Poultry Litter Ash as a Potential Phosphorus Source for Agricultural Crops. J. Environ. Qual. 31:954-961.

15. Myrie,S.,Bertolo, R., Sauer, W., and Ball, R. 2008. Effect of common antinutritive factors and fibrous feedstuffs in pig diets on amino acid digestibilities with special emphasis on threonine. J. Animal Science. 86: 609-619.

16. Quig, D. 1998. Cysteine metabolism and metal toxicity. Alternative Medicine Review.3:262-270.

17. New Jersey Feed Lab Inc., Trenton, NJ. 
Table 1. Proximate analysis values of poultry litter ash. Samples were run in duplicate. Values are reported as the average percent of the runs.

\begin{tabular}{|l|c|}
\hline & $\%$ \\
\hline Moisture & 2.155 \\
\hline Crude Protein & 11.4 \\
\hline Crude Fat & 0.23 \\
\hline Crude Fiber & 11.58 \\
\hline
\end{tabular}

Table 2. Mineral content of poultry litter ash. Samples were run in duplicate. Values are reported as the average percent of the runs.

\begin{tabular}{|l|c|}
\hline & $\%$ \\
\hline Calcium & 9.115 \\
\hline Phosphorus & 5.52 \\
\hline Sodium & 2.64 \\
\hline Water Soluble Phosphorus/ NPP & 2.8 \\
\hline
\end{tabular}


Table 3. Diet formulation. Diet 2 was comprised of 25\% NC and 75\%PC. Diet 3 was comprised of 25\% $\mathrm{NC}$ and $75 \% \mathrm{PC}$.

\begin{tabular}{|c|c|c|c|c|c|}
\hline Ingredient & Diet $1(\mathrm{NC})$ & Diet $4(\mathrm{PC})$ & Diet 5 & Diet 6 & Diet 7 \\
\hline & $\%$ & $\%$ & $\%$ & $\%$ & $\%$ \\
\hline Corn & 51.46 & 51.46 & 51.47 & 63.09 & 58.19 \\
\hline Soybean Meal & 31.56 & 31.56 & 31.56 & 29.49 & 28.71 \\
\hline Soybean Oil & 3.96 & 3.96 & 3.96 & 0.88 & 2.55 \\
\hline MBM & 3.00 & 3.00 & 3.00 & 3.00 & 3.00 \\
\hline Limestone & 1.29 & 1.07 & --- & 1.33 & 0.20 \\
\hline Salt & 0.39 & 0.26 & --- & 0.32 & 0.001 \\
\hline Methionine & 0.36 & 0.36 & 0.36 & 0.34 & 0.37 \\
\hline $\mathrm{NB} 3000^{\mathrm{A}}$ & 0.25 & 0.25 & 0.25 & 0.25 & 0.25 \\
\hline Lysine & 0.17 & 0.17 & 0.17 & 0.21 & 0.26 \\
\hline Threonine & 0.15 & 0.15 & 0.15 & 0.15 & 0.18 \\
\hline Defl. Phos. & 0.25 & 1.30 & $\begin{array}{ll}-- \\
--\end{array}$ & 0.80 & --- \\
\hline Coban $^{\mathrm{B}}$ & 0.08 & 0.08 & 0.08 & 0.08 & 0.08 \\
\hline $\mathrm{BMD}^{\mathrm{C}}$ & 0.05 & 0.05 & 0.05 & 0.05 & 0.05 \\
\hline Sand & 7.04 & 6.33 & 2.07 & --- & --- \\
\hline PLA & --- & --- & 6.89 & --- & 6.16 \\
\hline Optiphos $^{\mathrm{D}}$ & --- & --- & --- & 0.01 & 0.01 \\
\hline \multicolumn{6}{|c|}{ Calculated Nutrient Analysis } \\
\hline $\mathrm{ME}(\mathrm{kcal} / \mathrm{kg})$ & 1394 & 1394 & 1394 & 1394 & 1394 \\
\hline $\mathrm{CP}(\%)$ & 21.94 & 21.94 & 22.73 & 21.94 & 21.94 \\
\hline Lysine (\%) & 1.28 & 1.28 & 1.28 & 1.28 & 1.28 \\
\hline Meth+Cys (\%) & 0.98 & 0.98 & 0.98 & 0.98 & 0.98 \\
\hline Calcium (\%) & 0.80 & 0.91 & 0.91 & 0.91 & 0.91 \\
\hline Non-Phytate Phos (\%) & 0.23 & 0.45 & 0.37 & 0.45 & 0.45 \\
\hline
\end{tabular}

${ }^{\mathrm{A}}$ Supplied per kg of diet: manganese, 0.02\%; zinc 0.02\%; iron, 0.01\%; copper, 0.0025\%; iodine, 0.0003\%; selenium, 0.00003\%; folic acid, $0.69 \mathrm{mg}$; choline, $386 \mathrm{mg}$ ' riboflavin, $6.61 \mathrm{mg}$; biotin, $0.03 \mathrm{mg}$; vitamin $\mathrm{B}_{6}, 1.38 \mathrm{mg}$; niacin, $27.56 \mathrm{mg}$; pantothenic acid, $6.61 \mathrm{mg}$; thiamine, $2.20 \mathrm{mg}$; manadione, $0.83 \mathrm{mg}$; vitamin $\mathrm{B}_{12}, 0.01 \mathrm{mg}$; vitamin $\mathrm{E}, 16.53 \mathrm{IU}$; vitamin $\mathrm{D}_{3}, 2133 \mathrm{ICU}$; vitamin A, $7716 \mathrm{IU}$.

${ }^{\mathrm{B}}$ Active drug ingredient Monensin Sodium $60 \mathrm{gpb}(90 \mathrm{~g} /$ ton inclusion), Elanco Animal Health, Indianapolis, IN. As an aid in the prevention of coccidiosis caused by Eimeria necarix, Eimeria tenella, Eimeria acervulina, Eimeria brunette, Eimeriamivati, and Eimeria maxima.

${ }^{\mathrm{C}}$ Bacitracin Methylene Disalicylate $50 \mathrm{~g} / \mathrm{lb}$ (50 g/ton inclusion), Alpharma, Fort Lee, NJ. For increased rate of weight gain and improved feed efficiency.

${ }^{\mathrm{D}}$ Phytase (Optiphos, JBS United Inc., Sheridan, IN). 
Figure 1. The effect of PLA on pellet mill relative electrical energy

${ }^{\mathrm{a}-\mathrm{b}}$ Means within a column without a common superscript differ significantly $(\mathrm{P} \leq 0.05)$.

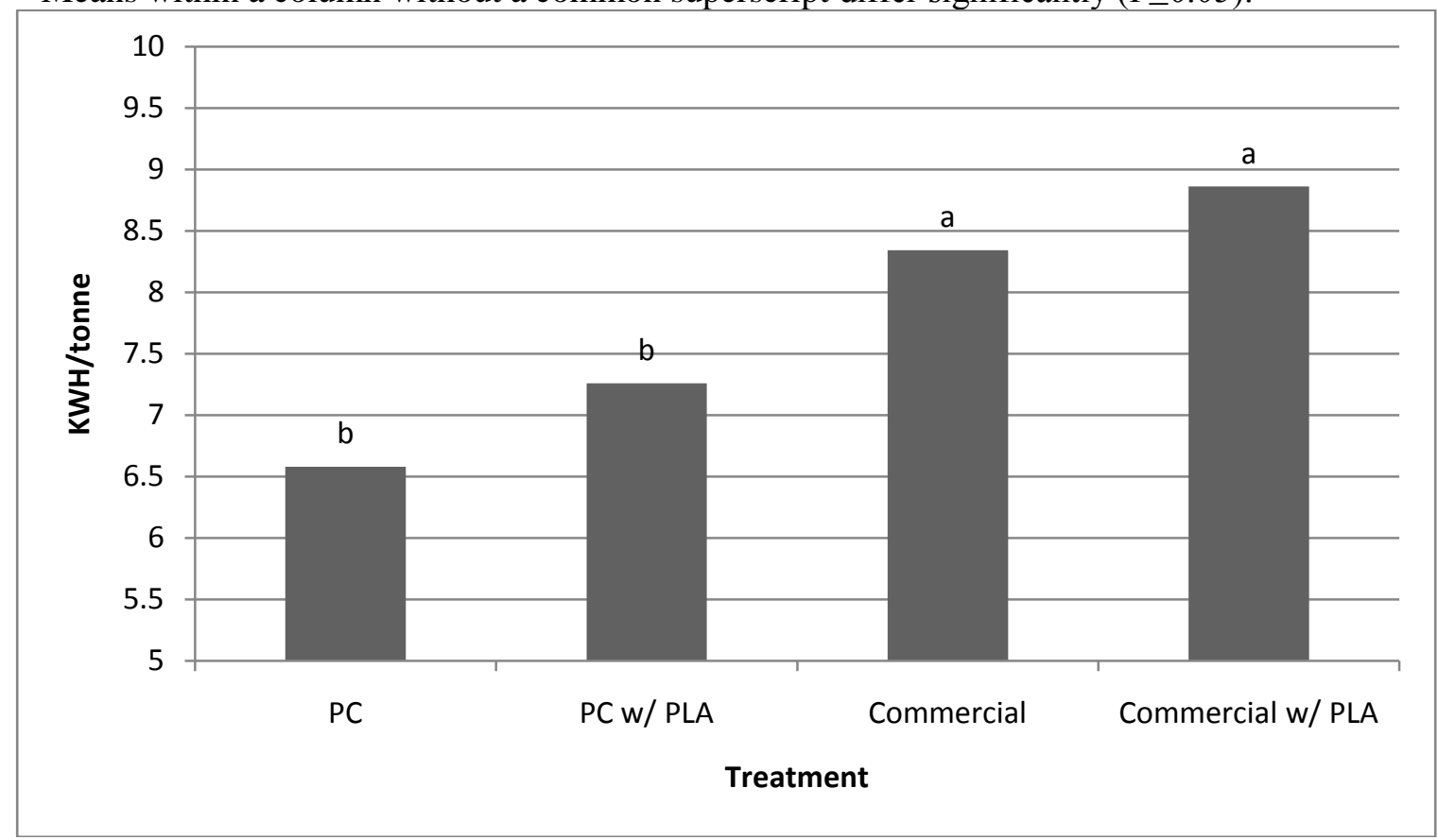

Figure 2. The effect of PLA on production rate.

${ }^{\mathrm{a}-\mathrm{b}}$ Means within a column without a common superscript differ significantly $(\mathrm{P} \leq 0.05)$.

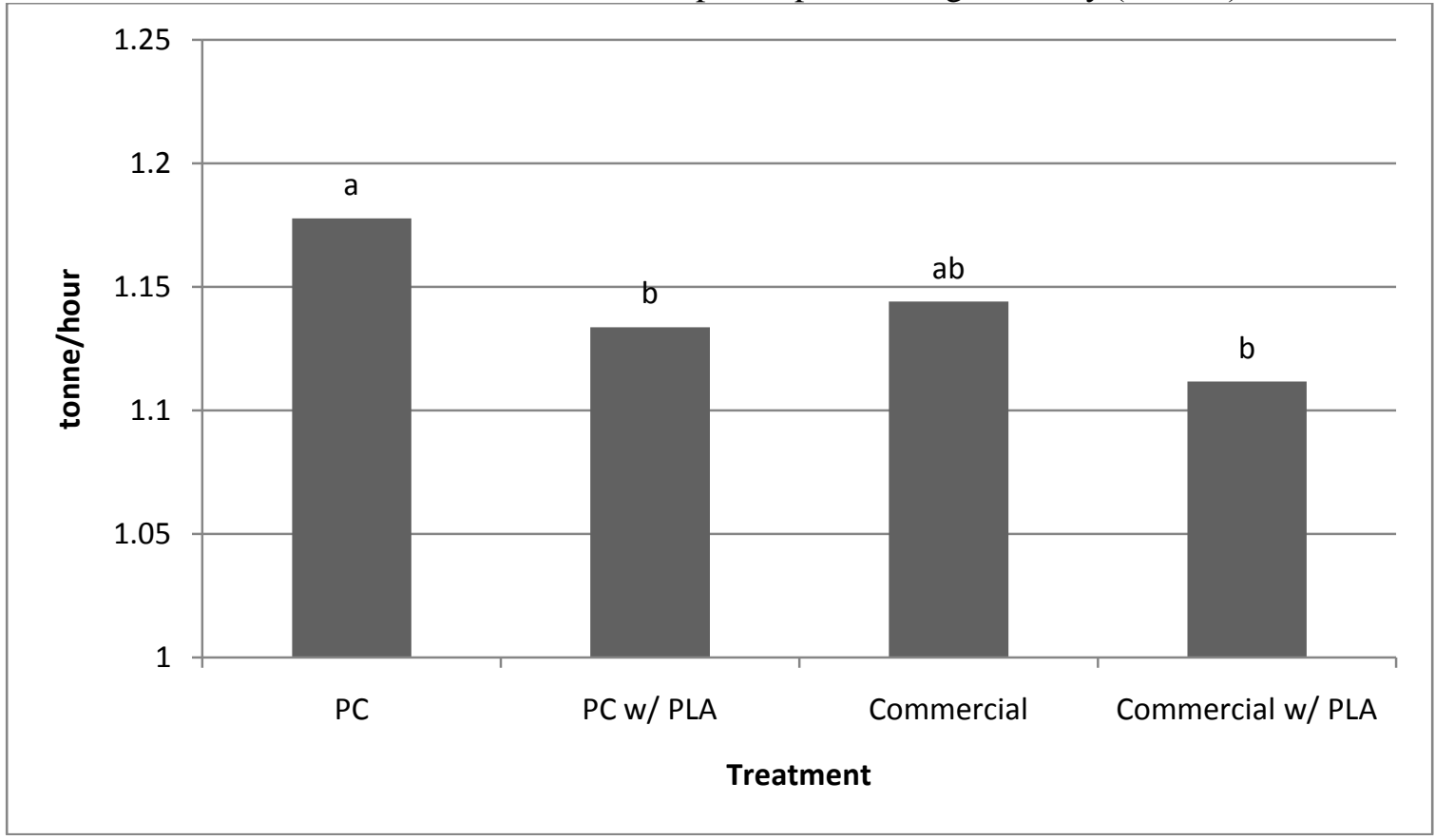


Figure 3. The effect of PLA on pellet durability index

${ }^{\mathrm{a}-\mathrm{c}}$ Means within a column without a common superscript differ significantly $(\mathrm{P} \leq 0.05)$.

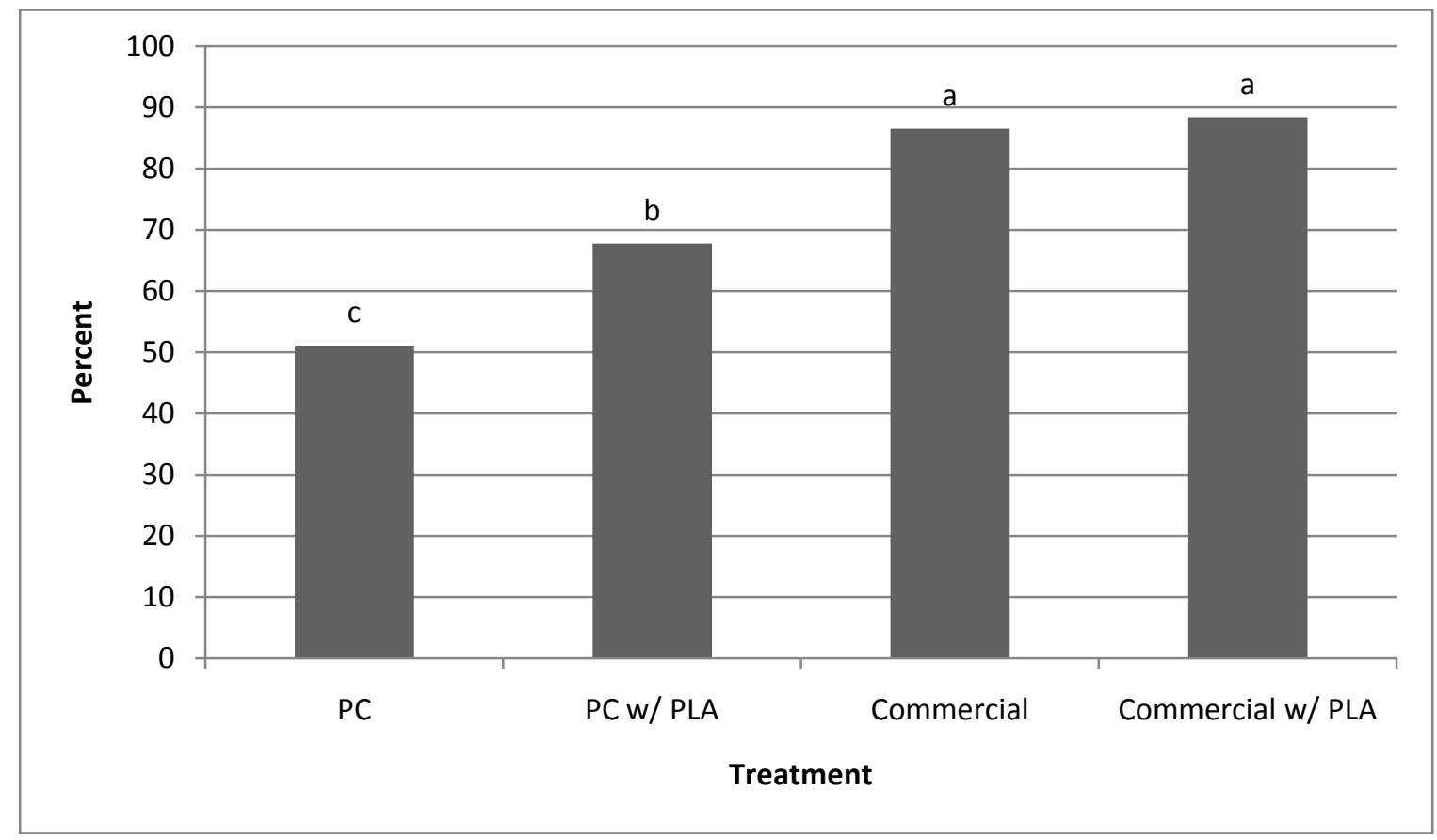

Figure 4. The effect of PLA on feed intake of chicks from d3-d21

${ }^{\mathrm{a}-\mathrm{c}}$ Means within a column without a common superscript differ significantly $(\mathrm{P} \leq 0.05)$.

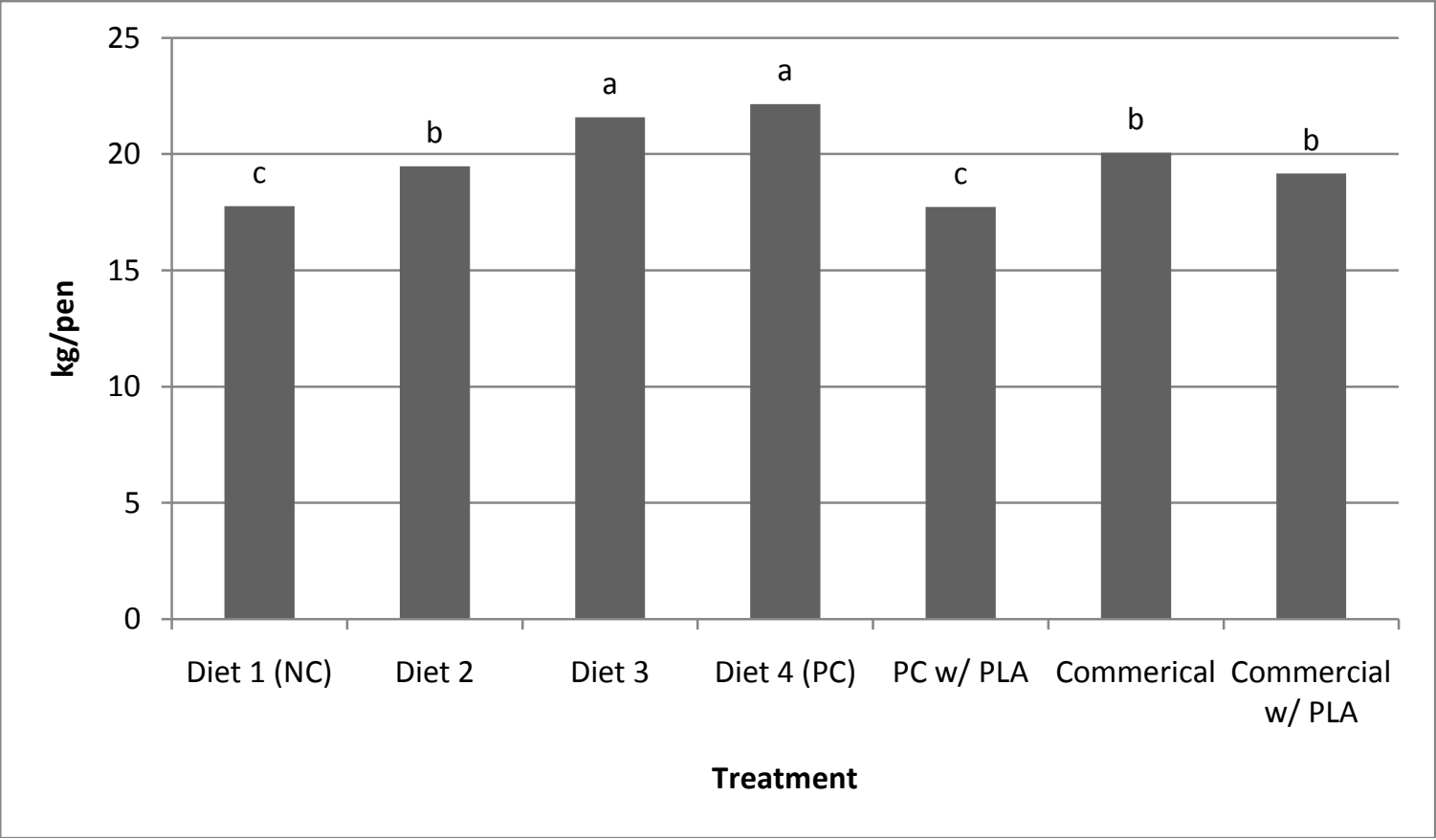


Figure 5. The effect of PLA on live weight gain of chicks from d3-d21.

${ }^{\text {a-c }}$ Means within a column without a common superscript differ significantly $(\mathrm{P} \leq 0.05)$.

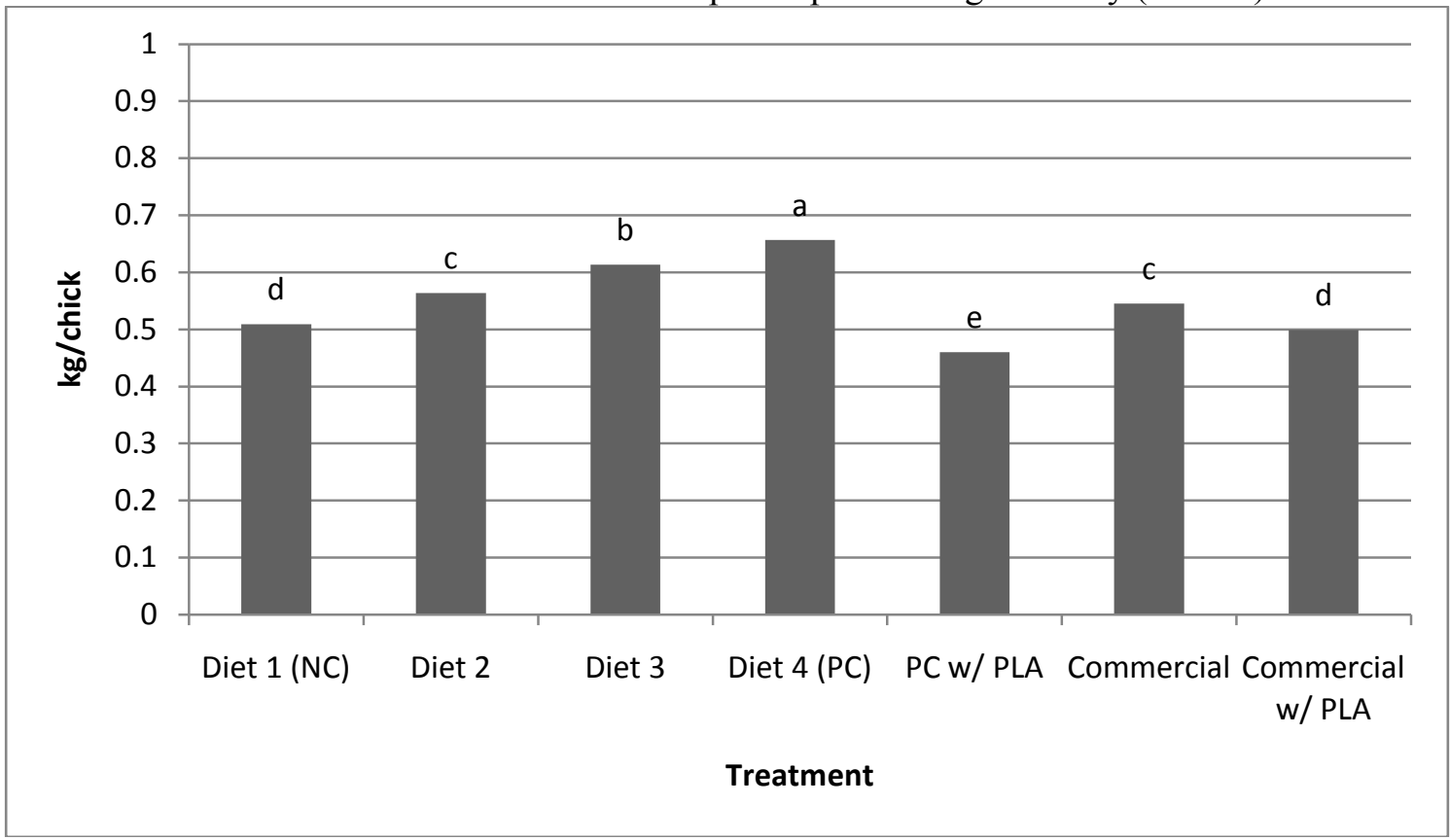

Figure 6. The effect of PLA on feed conversion ratio of chicks from d3-d21.

${ }^{\mathrm{a}-\mathrm{c}}$ Means within a column without a common superscript differ significantly $(\mathrm{P} \leq 0.05)$.

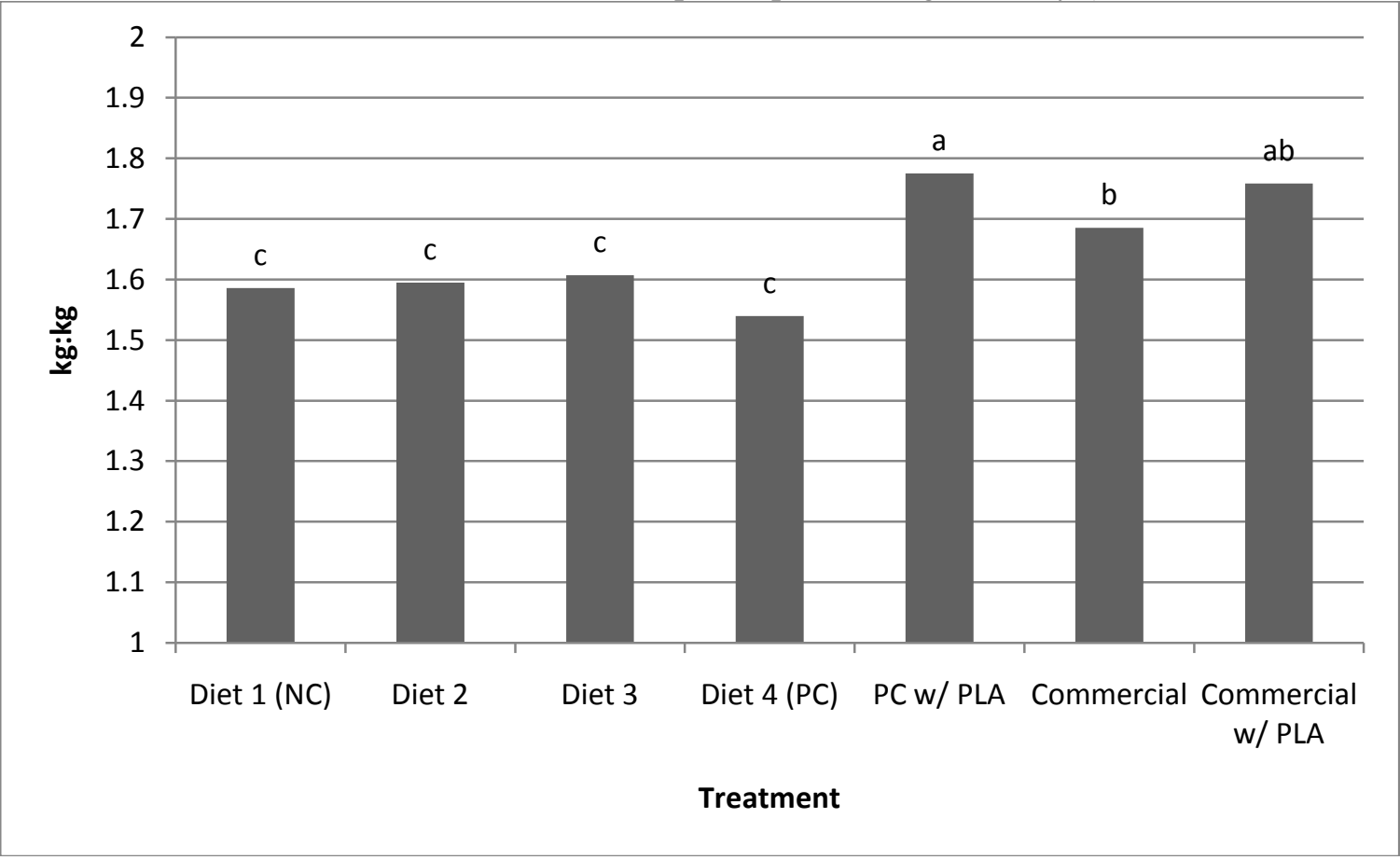


Table 4. The amount of heavy metals found in poultry litter ash.

\begin{tabular}{|l|l|}
\hline Heavy Metal & Amount \\
\hline Arsenic & $99 \mathrm{ppm}$ \\
\hline Nickel & $48 \mathrm{ppm}$ \\
\hline Chromium & $29 \mathrm{ppm}$ \\
\hline Cobalt & $5 \mathrm{ppm}$ \\
\hline Lead & $2 \mathrm{ppm}$ \\
\hline Cadmium & $0.4 \mathrm{ppm}$ \\
\hline Aluminum & $1.2 \%$ \\
\hline
\end{tabular}

Figure 7. The effect of PLA on tibia ash of chicks from d3-d21.

${ }^{\mathrm{a}-\mathrm{c}}$ Means within a column without a common superscript differ significantly $(\mathrm{P} \leq 0.05)$.

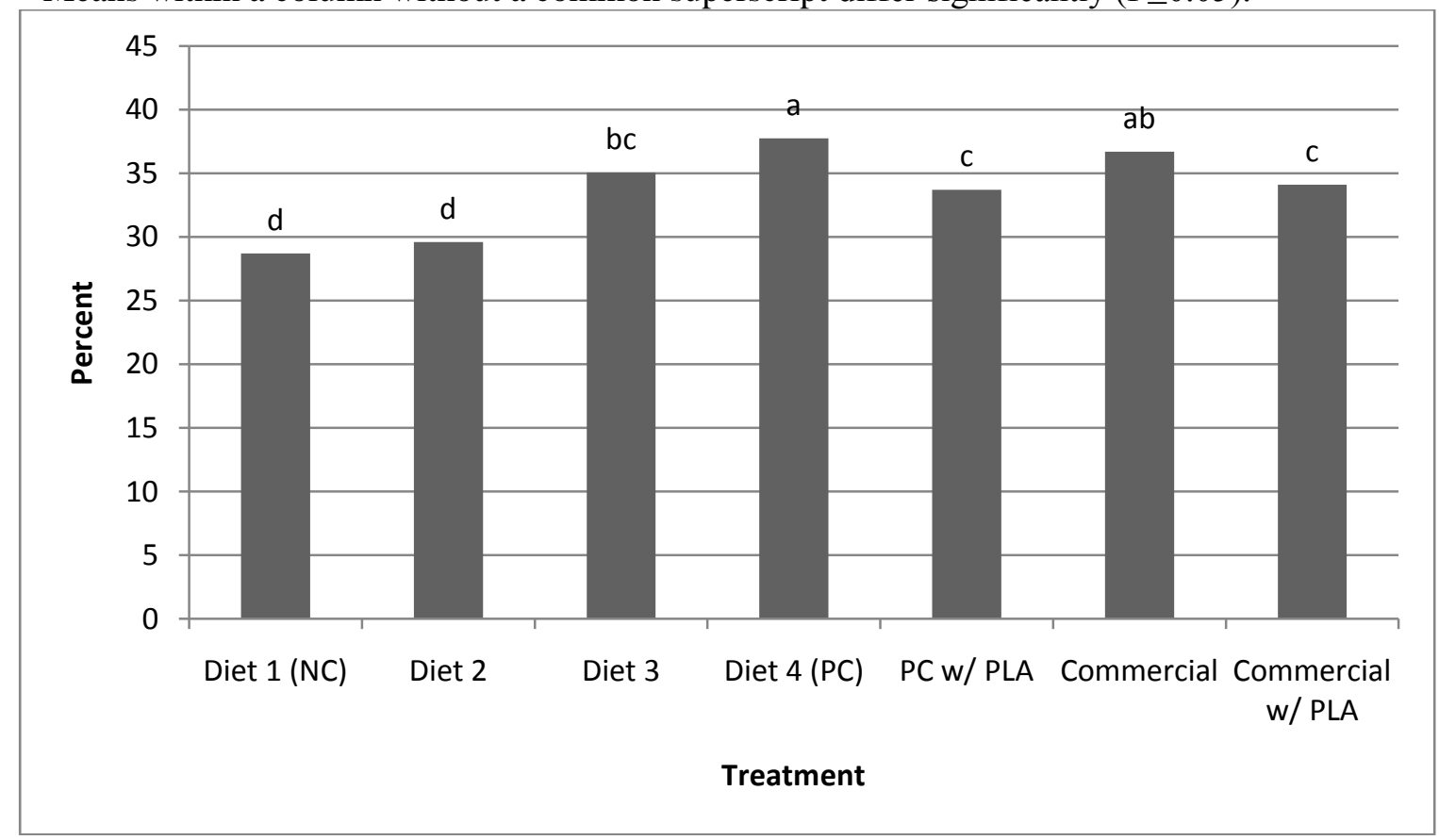

